\title{
胃液分泌特二胃底腺分泌二關スル 實驗的研究（第一報）
}

\section{Pawlow 小胃(胃底腺盲霓)犬二於ケル正常 \\ 胃液分泌二就广}

東京帝國大學傳染病研究所附凰醫院 (主任 宮川数授)

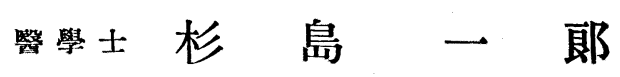

目 次

第一章 緒言站二實驗方法

第二章 Pawlow 小胃手術後第三週以內 , 胃 液分泌狀態

第三章 Pawlow 小胃手術後第三週經過後，

\section{賁液分泌狀態}

第四章 中和胃液注入實驗

第五章 胃液酸度站 $=$ Pepsin 二就テ

第六章 總括及ビ結論

主要文獻

\section{第一章 緒言站二蒉驗方法}

1894 年 Heidenhain

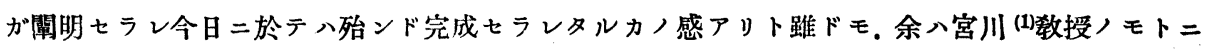
アリテ直接作用ナル假須ノモト二暴二耳下腺分泌 (2)二關スル研究 $ヨ$ 報告 シ今回胃液分泌二關ス ル研究二從事スルヤPawlow 小胃二就キテ認メ得タル正常胃液分泌機轉二關シ同数授, 説二該 當スル三三ノ事實二遭遇シタルヨ以テ立二聊カ卑見ヨ報ゼント欲スルモノナリ。

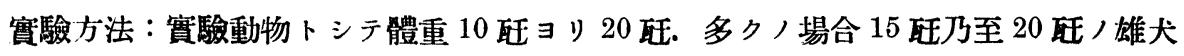
キ選ビ之レニ Pawlow 小胃手術タ施行セリ. 胃液探取方法トシテハ成ル可ク瘻孔口 キ損傷セザル目的ニテ直徑 $1.0 \mathrm{~cm}$ 長サ $5.0 \mathrm{~cm}$ ニシテ比較的軟質ノ護謨管ノ一端き二

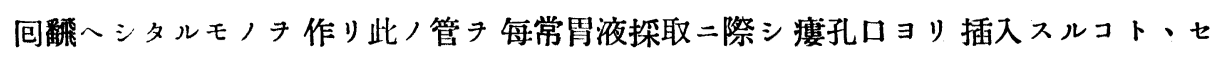

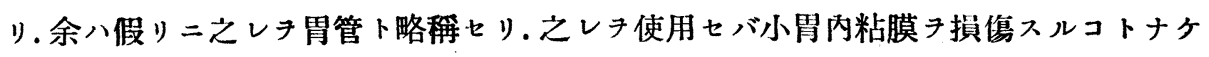
レドモ稀二瘦孔開口附近ョリ血液及ビ其他ノ組織液ノ出ヅルコトアリ. 殊二流出胃液

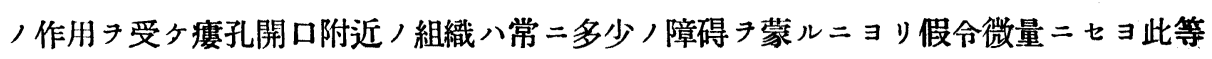
血液及ビ其他ノ組織液ガ探取胃液二混入スルトキハ之レ二種々八著色站二白濁等き來 サシムルノミナラズ胃液检查ノ結果ニモ影響キ及ボス事甚大ナル二鑑に余八胃管插入

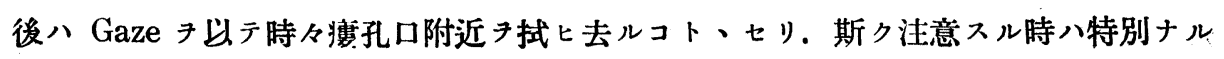
場合ヨ除ク外. 小胃内ヨリ八每常全ク水樣透明ナル胃液キ採取スルコトヨ得。實驗二 
際シテハ每常犬ョ實驗用犬固定器二繫グコト、セリ。

胃液酸度ニ對シテハ $1.0 \%$ Phenolphthalein キ指示藥トシテ總酸度测定シ。 0.5

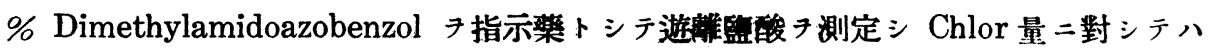

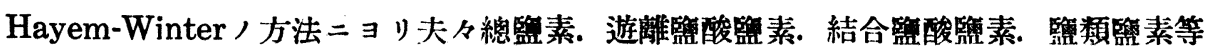
キ測定七リ。 叉 Pepsin 測定二ハ Fuld-Laevison，Edestin法. Chymosin，測定二 八 Michaelis-Rothstein 法二據レリ。

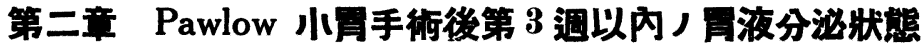

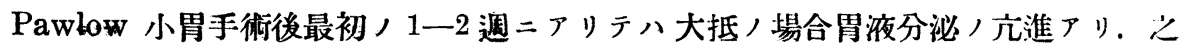
レ日々實驗二際シ試驗食キ與へタル場合容易二觀察シ得ラル、事實ナリ。而シテえレ 八蜜口正常, 胃液分泌ニハアラズシテ手術ト云フーツノ外的刺戟二因リテオコリタル 生體ノ一反應卜見做スベキモノニシテ之ハ犬ノ手術後每常觀察セラル、所，所見ナ リ. 同樣, 事實八唾液腺瘻孔. 膵䑏瘦孔. 腸瘦孔手術後二於テモ亦認メラル、モノナ レドモ。カノ Cl. Bernard, Heidenhain, Langley, Bradford 等二依りテ發見七ラ レタル腦分泌神經郎千鼓索神經切斷後顩下腺ヨリ間斷ナク喠液, 分泌七ラル、事實。

Cl. Bernard，所謂 Paralytische Sekretion 魔痹性分泌卜ハ多少ソ/诹子異二セル、 ガ如シ。斯カル犬二於テハーツハ膺孔ロキ絕ェズ䑛ムル關係モアランガ. 仯本常二糊 帶キ施シタル場合二モ早朝空腹時二於テ著明ナル胃液ノ分泌アルキ認メ。ソノ總酸度 遊雄祭酸度站ビ二酵素力等何レモ高度ニシテ後述スル所ノ正常空腹時胃液ノ比二非 ㅈ․ 而シテ此八際胃液八多量ノ粘液き含有セリ。斯カル胃液分泌殊二空腹時罗液分泌

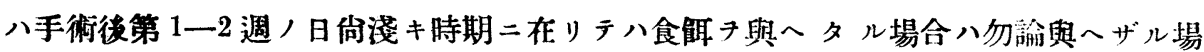
合二モ 1 日中絶ェズ行ハレ且ツ大凡 30 分位ノ間隔キ置キ小胃蠕動卜共二週期的二分 泌增量スルモノナル事キ經驗スルキ得タリ。小胃蠕動八瘦孔口二於テ小胃粘膜が時 ヨオキテ週期的二翻轉性二突出シ來ルニ依リテえレチ認識スルコトチ得. 斯カル場合 先ジ粘液乃至粘液片, 流出アリ。えレニ引續キ胃液分泌ノ增量き來シ整時ニシテ再ビ 減量シ次二胃蠕動，起ルト共二粘液分泌，增加二引續キ又胃液分泌，增量き呈ス.

斯ノ如ク手術後第 3 週以内，分泌八多數ノ犬二就キテ檢スル二多クノ場合週期的ナル 尹知レリ(第 1 表寥照)。之レチ例示スレバ次ノ如シ。

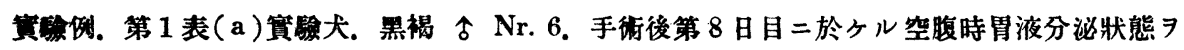

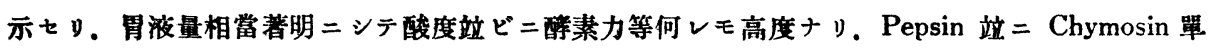
位互七二相站行七り，胃液量二八週期的增減アリ。 


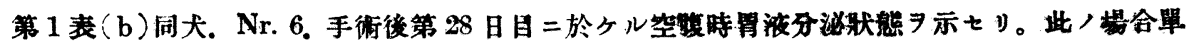
二粘液ノ流出スルヨ認メシノミナリ。

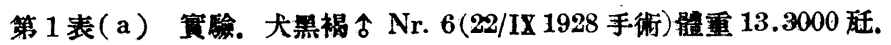

空儲時胃液探取

\begin{tabular}{|c|c|c|c|c|c|c|c|}
\hline $\begin{array}{l}\text { 時日(29/IX1928) } \\
\text { 手術後第 } 8 \text { 日目 }\end{array}$ & 胃 源 & $\begin{array}{l}\text { 㚆 } \\
\text { m. }\end{array}$ & 總酸度 & 遊離嚂酸 & $\begin{array}{c}\text { 總監素量 } \\
\%\end{array}$ & Pepsin & Chymosin \\
\hline $\begin{array}{l}8^{\mathrm{h}} 45^{\prime}-9^{\mathrm{h}} 0^{\prime} \\
\text { a.m. } \\
9^{\mathrm{h}} 0^{\prime}-15^{\prime} \\
9^{\mathrm{h}} 15^{\prime}-30^{\prime} \\
9^{\mathrm{h}} 30^{\prime}-45^{\prime}\end{array}$ & $\left.\begin{array}{l}0.75 \\
1.94 \\
1.45 \\
1.34\end{array}\right\}$ & 4.48 & 125.6 & 115.1 & 0.56 & 1920 & 580 \\
\hline $\begin{array}{l}9 \mathrm{~h} 45^{\prime}-10^{\mathrm{h}} 0^{\prime} \\
10^{\mathrm{h}} 0^{\prime}-15^{\prime} \\
10^{\mathrm{L}} 15^{\prime}-30^{\prime} \\
10^{\mathrm{h}} 30^{\prime}-45^{\prime}\end{array}$ & $\left.\begin{array}{l}0.45 \\
1.20 \\
1.44 \\
1.22\end{array}\right\}$ & 4.31 & 123.8 & 110.3 & 0.57 & 1920 & 520 \\
\hline 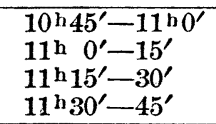 & $\left.\begin{array}{l}0.08 \\
0.28 \\
0.89 \\
1.20\end{array}\right\}$ & 2.45 & 110.4 & 94.8 & 0.58 & 2880 & 620 \\
\hline $\begin{array}{l}11^{\mathrm{h}} 45^{\prime}-12^{\mathrm{h}} 0^{\prime} \\
0^{\mathrm{h}} 0^{\prime}-15^{\prime} \\
0^{\mathrm{h}} 15^{\prime}-30^{\prime} \\
0^{\mathrm{h}} 30^{\prime}-45^{\prime}\end{array}$ & $\left.\begin{array}{l}1.05 \\
0.08 \\
0.15 \\
0.25\end{array}\right\}$ & 1.53 & 98.6 & 79.5 & 0.57 & 2880 & 780 \\
\hline $\begin{array}{l}0^{\mathrm{h}} 45^{\prime}-1 \mathrm{~h} 0^{\prime} \\
1^{\mathrm{h}} 0^{\prime}-15^{\prime} \\
1^{\mathrm{h}} 15^{\prime}-30^{\prime} \\
1^{\mathrm{h}} 30^{\prime}-45^{\prime}\end{array}$ & $\left.\begin{array}{l}1.10 \\
0.74 \\
0.10 \\
0.00\end{array}\right\}$ & 1.94 & 102.3 & 83.7 & 0.56 & 1920 & 580 \\
\hline $\begin{array}{l}1 \mathrm{~h} 45^{\prime}-2 \mathrm{~h} 0^{\prime} \\
2 \mathrm{~h} 0^{\prime}-15^{\prime}\end{array}$ & $\left.\begin{array}{l}0.33 \\
0.55\end{array}\right\}$ & 0.88 & 69.4 & 56.9 & 0.57 & 3840 & 1040 \\
\hline
\end{tabular}

第 1 表(b) 同犬 Nr.6 體重13.050䂡 空腹時胃液探取

\begin{tabular}{|c|c|c|}
\hline $\begin{array}{l}\text { 時日(19/X 1928) } \\
\text { 手術後28日目 }\end{array}$ & $\begin{array}{c}\text { 雷液量 } \\
\text { ccm. }\end{array}$ & \begin{tabular}{|l|} 
避 離 留酸酸 \\
Congo 試驗
\end{tabular} \\
\hline $\begin{array}{l}8 \mathrm{~h} 45^{\prime}-9^{\mathrm{h}} 0^{\prime} \\
\text { a.m }\end{array}$ & $\begin{array}{c}0.45 \\
(\text { 粘液) }\end{array}$ & $(-)$ \\
\hline $9^{\text {h }} \quad 0^{\prime}-15^{\prime}$ & $\begin{array}{r}0.30 \\
(\text { 粘液) }\end{array}$ & $(-)$ \\
\hline 9 n $15^{\prime}-30^{\prime}$ & 0 & • \\
\hline $9^{\mathrm{h}} 30^{\prime}-45^{\prime}$ & 0 & \\
\hline $9 \mathrm{~h} 45^{\prime}-10 \mathrm{ho}^{\prime}$ & 0 & \\
\hline $10^{\mathrm{h}} 0^{\prime}-15^{\prime}$ & $\begin{array}{r}0.10 \\
(\text { 粘液) } \\
\end{array}$ & $(-)$ \\
\hline $10^{\mathrm{h}} 15^{\prime}-30^{\prime}$ & 0 & \\
\hline $10^{\mathrm{h}} 30^{\prime}-45^{\prime}$ & 0 & \\
\hline
\end{tabular}

Nechoroschew ${ }^{(3)}$ モ亦犬 $ニ ッ キ$ 空腹 時胃液ノ週期的分泌 Babkin $^{(4)}=ヨ レ$ 斯カ ル'所見八消化管 ノ大ナル障碍タ來七ル時. 殊二同一犬二 多數/瘦孔キ一時二造リタル如キ場合二 特ニ見ラル、モノトナセドモ。要スルニ 之レハ手術ナルーツノ外的刺戟二因リテ 來ルモノニシテ㓜論一ツニハ分泌神經き 多少ナリトモ損傷セル關係モアランガ省 ホ犬ハ此ノ際絶エズ瘦孔口キ甜ムルニヨ リ棰液ノ分泌テ高メ從ツテ喠液ガ太胃二 送ラル、ト共二一方十二指腸液ガ斯カル 時期二於テハ特二霆了大胃內二逆流シ來ル關係上大胃ノ分泌告起シ第メ二小胃ノ分 泌きモ同時ニ促ガスモノト思惟ス。晑又此ノ時期二於テ特二注意き要スルコトハPaw-

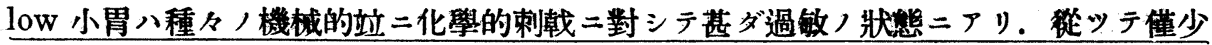


〉刺戟モ容易二分泌 催進シ得ル點ニアリトス. 例之余ノ實驗二徵スルニ手術創ノ治 瘾キ促ガサントシ乃至ハ治瘾後ト雖ドモ瘦孔部位ノ污物キ洗ヒ落サントシ Oxyfull, Rivanol 等, 比較的濃厚ナル藥液き無意識二局所二適用シタル後胃液き採取セントシ テ胃管テ小胃內へ插入シタル時意外二モ突然多量，胃液ノ流出スルタ認ムルコトアリ (第 2 表參照)。以上, 事實キ例示スレバ次ノ如シ。

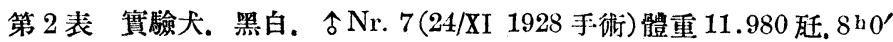
胃管习插入シ胃液ノ流出ナキヨ磪カメ $8^{\mathrm{h}} 30^{\prime}$ 胃管习除去シ瘦孔 口ヨ Oxyfull $\ni$ 以テ洗湺。 $8 \mathrm{~h} 40^{\prime}$ 再ビ胃管习插入シ胃液习探取

\begin{tabular}{|c|c|c|c|c|c|}
\hline $\begin{array}{l}\text { 時日 (8/XII 1928) } \\
\text { 手術後第15日目 }\end{array}$ & $\begin{array}{c}\text { 胃 液 量 } \\
\text { ccm. }\end{array}$ & 總 酸 度 & 遊離籃酸 & 總籃素量 & Pepsin \\
\hline $\begin{array}{l}8 \mathrm{~b} 0^{\prime}-15^{\prime} \\
\text { a.m. }\end{array}$ & (粘液) & & $\begin{array}{l}\text { Congo } \\
\text { 弱陽性 }\end{array}$ & & \\
\hline 8 h $15^{\prime}-30^{\prime}$ & 0 & & & & \\
\hline 8 b $40^{\prime}$ 胃管插入 & 7.8 & 135.2 & 129.5 & 0.56 & 480 \\
\hline $\begin{array}{l}8 \mathrm{~h} 45^{\prime}-9 \mathrm{~h} 0^{\prime} \\
9 \mathrm{~h} 0^{\prime}-15^{\prime} \\
9 \mathrm{~h} 15^{\prime}-30^{\prime} \\
9 \mathrm{~h} 30^{\prime}-45^{\prime}\end{array}$ & $\left.\begin{array}{l}1.42 \\
0.19 \\
0.22 \\
0.32\end{array}\right\} 2.15$ & 120.9 & 112.0 & 0.57 & 480 \\
\hline
\end{tabular}

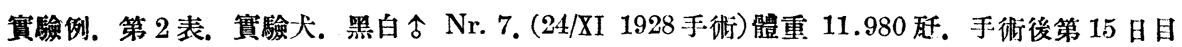
師チ8/XII 1928 午前 8 時 0 分胃管习插入シ胃液八流出殆ンド無キヨ磪カメ 8 時 30 分胃管习除去

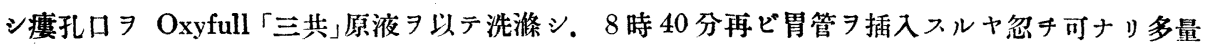
, 胃液が一時二流出セシヨ見タリ。然レドモ其後, 分泌八試驗食投與, 啺合卜比較シ餘り久シ ク持長セザルモノ、如シ。

斯カル所見八後述スルトコロノ手術後大凡 $3-4$ 週, 經過後二於テ認メラル、正常 胃液分泌，時期二於ラ八觀察七ラル、事至難トナルモ少ホ時二胃管キ以テ無暗二機械 的二胃壁き刺戟シタル場合ニ八胃液分泌量ノ增加キ來スノミナラズ佮空腹時分泌キモ 招來セシムルコト無キニ非ズ. Pawlow 站ビニソ，學徒ノ研究ニョレバ胃幽門部粘膜 テ隔離シ置キ胃底部粘膜へ與へタル機械的站二化學的刺戟八笔モ胃液分泌子惹起シ得

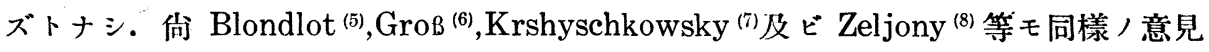
キ發表シ居レルガ. Lim, Ivy，泣ビ $=$ McCarthy ${ }^{(9)}$ 八Frémont/,,estomac sequestré” キ有スル犬ニッキ Ballon，助ケニョリえレキ擴張セシメタル時八分泌，增 加スルコトチ認メタリ。余，Pawlow 小胃犬二就キテ觀察セル上述ノ現象八手術後 短時日二於テハ特二著明ナルニ低リ手術後 3 週間以內二實驗キ行フニ當りテハ此ノ點 三多少ノ注意要スルモノナラント考へラル。

\section{第三章 Pawlow 小胃手術後第 3 涸艖過後ノ骨液分泌状態}

手術後 3 週間キ經過セル後ニアリテハPawlow小胃ハ種々ノ藥物立ビ二試驗食ノ一 
定量二對シ略了一定, 態度キ示スニ至ル。早朝空腹時二胃管タ插入シ胃液き探取スル 二最初二於テ粘液, 流出アリ。之空腹時二於テハ胃粘膜ハ一樣二粘液キ以テ覆ハル ルガ第メニシテ胃內八所謂粘液海, 像き呈セリ. 而シテソノ際酸度八特二低クシテ多

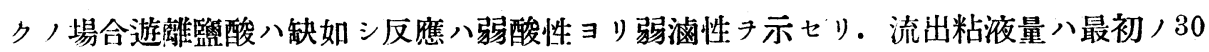
分間二最モ多クシテ大凡 0.3 乃至 $1.0 \mathrm{ccm}$. タ算ス. $1.0 \mathrm{ccm}$. タ超ュルコト殆ンド稀ナ リ. 粘液ノ流出キ終レバ通例胃液, 分泌認メズ．但三過酸症乃至胃液分泌過多ノ犬

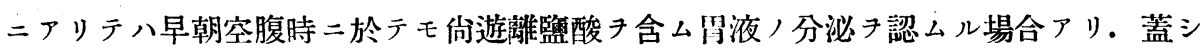
余ノ經驗二於テハ過酸症ノ場合ハ手術創ノ治瘾二長時日ナ要シ且ツ完至ナル治痛八困 難ナルニ反三減酸症, 場合二治癒, 頗ル容易ナル八瘦孔部位, 消化液二作用サル、コ トノ尠キガ焦メナリ。次二試驗食キ投與スル二食事中八大抵ノ場合胃液ノ分泌アルタ 涩メズ. 蓋シ咀嚼チナシ喠液ノ分泌ガ開始セラレ唾液腺ノ旺盛ナル活動期ニアリテハ 假令食物ガ胃内へ輸途七ラル、トモ未ダ直チ二八胃液分泌荧起スルニ至ラザルモ，

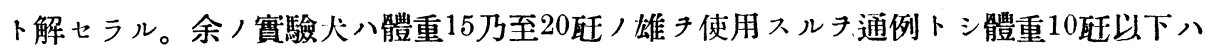
使用セシコト殆ンド稀ナリ、而シテ斯カル犬ニツキ試驗食トシテ通常米钣 250 瓦. 馬

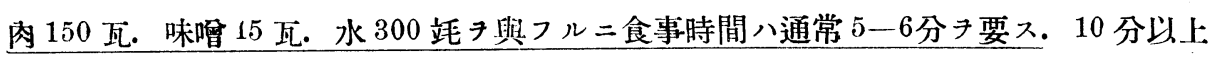
ヨ要スル場合八稀ナリ. 又少シク速カナル場合ニ八往々 3 分ノコトアリ. 又例外トシ テ 2 分以內二食シ終レル場合スラアリ. 然レドモ何レ, 場合ニモ食シ終リタル後始メ テ胃液ノ分泌開始セル、チ見タリ。以上ハ孯腺ガ最初全ク靜止ノ狀態ニアリタル場合

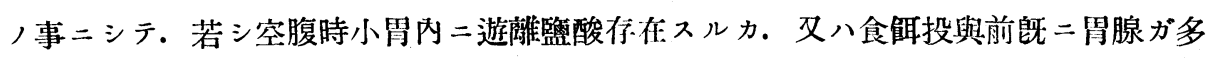
少トモ活動七ル場合二八試驗食投與卜同時二胃液, 胃管丹通シテ落下スルチ認ムレド モ向ホ立二明カ二觀察サル、事實ハ郎チ既二著明ナル胃液ノ分泌アリテ胃管ヨリ胃液

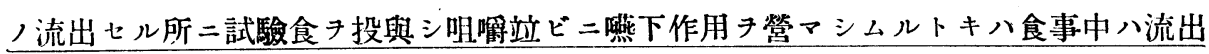
胃液量ノ大 1 二減少スル點ニアリ. 次二食事終了後胃液分泌ノ開始七ラル、过ノ時間 二モ食事速度二相當シテ長短アリ．從ツテ食事時間ノ短キモノ郎チ食事速度ノ大ナル モノ程胃液分泌ハ一層速カ二塋起七ラル、ガ如シ. 郎チ食後直チ二分泌ノ起ル場合. 之レハ多ク食事速度,大ナルモノ二見ラル。然レドモ一般二食後分泌，開始七ラル、 迄二ハ一定ノ間隔アリ. 余八遊離監酸ノ出現テ以テ分泌ノ開始七ラレタル徵トナセル ガコノ間液ノ流出全ク無キカ或ハ粘液ノ流出アリ乃至ハ Congo 陰性二シテ比較的稀 薄ナル液ノ流出アルキ認ム。コノ間 3 分ヨリ 5 分キ要スル場合多シ.然ル後 Congo 陽

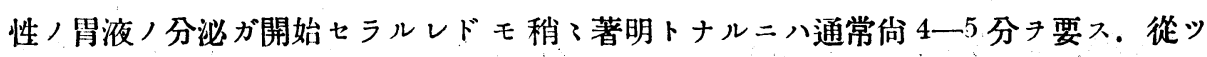
テ食事ノ始メヨリ胃液分泌ノ著明トナル迄二ハ大凡 15 分八間隔アリ 15 分ヨリ 45 分 


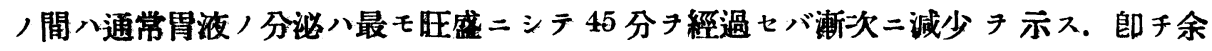
ノ試䐘食投與二於テ八最初, 1 時間二於テ最モ多量, 胃液み探取スルコトタ得. 第 2

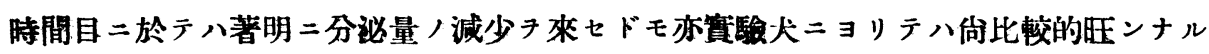

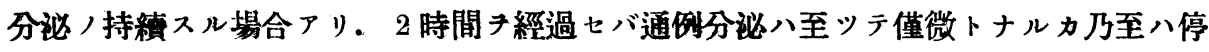

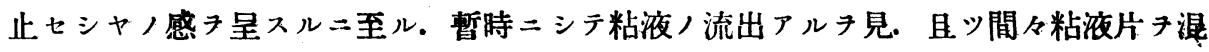
在ス. 斯ノ如ク胃液分泌ノ末期ニアリテハ必ズ粘液ノ流出刃認ムルモノナレドモとレ ト共二一旦甚シク微弱トナリタル分泌モ幾分增量き來入. 而シテ粘液殊二粘液片ハ15 分乃至 30 分及ビ時ニハソレ以上, 間隔キ置キ稍了週期的二分必ノ行ハル、モノニシ テ此ノ粘液分泌二伴ヒ胃液モ極少量宛分泌七ラレ. 斯クシテ日中八常二極メテ少量宛 ト雖ドモ分泌持續ス. 而シテ手術後 3 週間以内ノ比較的日淺キ實驗犬ニアリテハ此 現象ノ特二著明ナルハ上述セル所ナリ。夜二入リ睡眠ニトルニ至レバ胃液ノ分泌八全

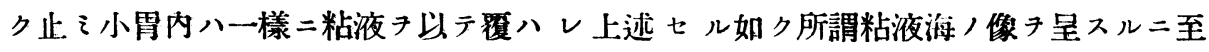
ル. 翌朝二至り胃液採取管タ新タニ小胃內二插入スル二胃液ノ流出アルフ認メズ. 漸 次ニシテ徐々二粘液,流出スルフ認ム。以上ハ余が手術後 3 週間以上キ經過七ル實驗 犬二於テ每早朝規則正シク翼便及ビ尿フ排泄セシメ然ル後實驗用犬固定器二繋ギ胃液 探取管キ插入シ粘液ノ流出キ終リタル後一定試驗食キ投與シテ逐次觀察シ得タル分泌 ノ經過ニシテ換言スレバ之八試驗食投與ニョル胃液分泌ノ自然的經過トモ考へラル、 所ニシテ次圖實驗例二就キテ說明スベシ。

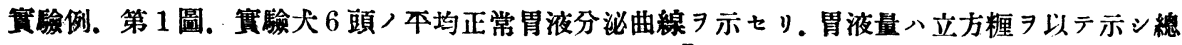

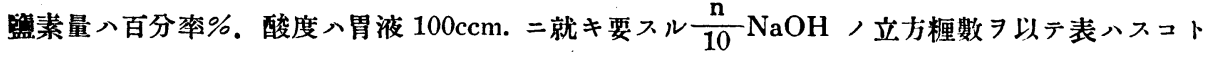
トセリ。早朝空腹時胃管 ヨ插入スルニ粘液ノ流出アルノミニシテ Congo 陽性, 胃液分泌アル 認メブ. 15 分每二分割的二探取スル二流出粘液量、 15 分目 $=0.4 \mathrm{ccm} .30$ 分目 $=0.15 \mathrm{ccm} .+リ$

第 1 圖 實驗大 6 頭，本均正常分䎵曲線手術後第 28 日目

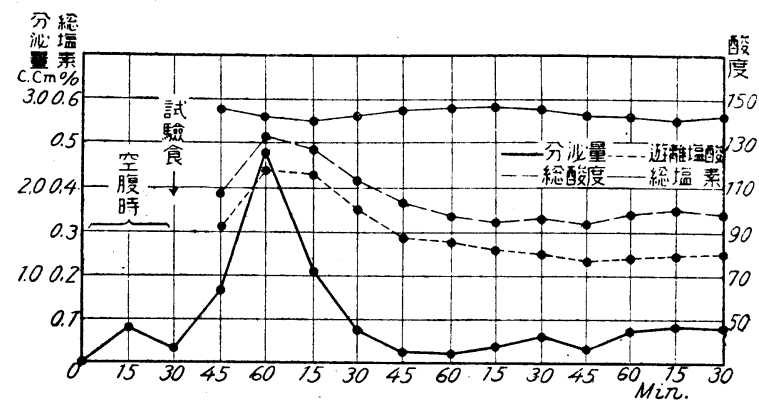

試驗会投興後 15 分ョリ 45 分迄八間八分泌八最モ旺盛 ナルヨ知ル。ソ，量 3.48 ccm. ナり試驗食投奥後 60 分間量 $4.66 \mathrm{ccm}$. ナリ試驗 食投興後 3 時間ニシテ分泌 量/多少增加七ル八分泌胃 液量，增加以外二分泌粘液 量ノ墙加アルが第メナリ。 酸度二關シテハ總酸度遊熭 蜜酸度八互二相站行七り。

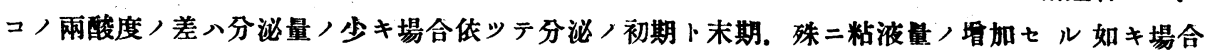

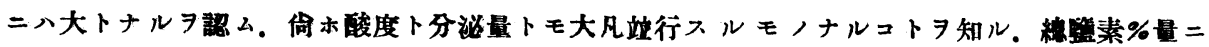




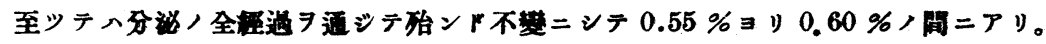

第 2 圖。正常胃波分泌曲線中往々ニシテ見受ケラル、型ヨ示七リ. 空腹時胃腺八全ク䱢止ノ狀 態ニアリテ Congo 陽性ノ胃液分泌アルラ認メズ. 唯粘液ノ流出アルヨ認ムルノミナリ.ソノ30

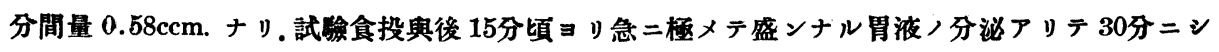
テ最高二達シ以後 45 分目迄二分泌量急㓺二減少 7 來セル如キ埸合へ次二再ビ比㜞的著明ナル分 泌ノ上昇 $习$ 伴フコトアリ。 第 2 圆正常胃液分消曲線

斯カル場合ト雖ドモ第 1 圖 二於ヶルト同樣酸度八分泌 量ト大凡站行スルコトヨ知 ル。向木總酸度卜遊離酸酸 度卜八互二相站行スルラ認 ム、總留素\%量八殆ンド不 焚ナり。以上八余ノ武倹食 ヨ投與セシ際二最モ磨 、道 遇シタル分泌型 ヨ示シタル

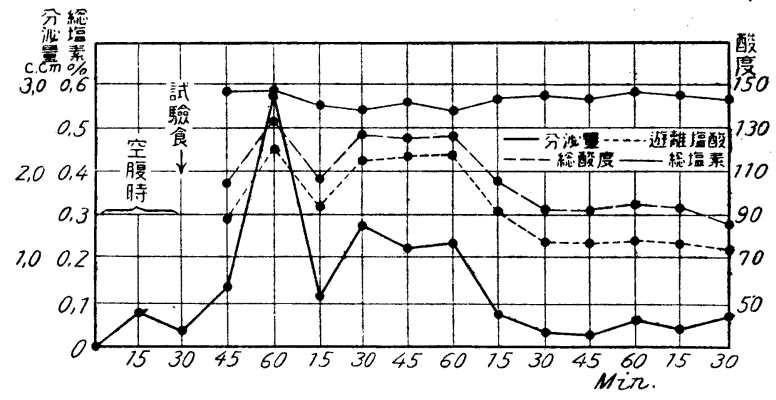
二過ギブ，場合ニョリテハ

勿論種タナル分泌型アレドモ茲ニ八省略スルコト、セリ。余，實驗犬二、試驗食トシテ以上記

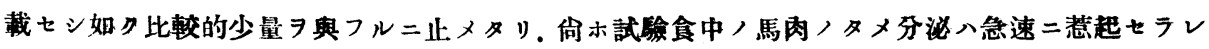

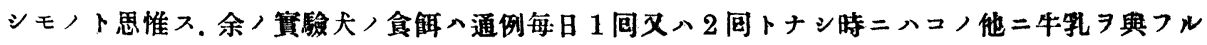

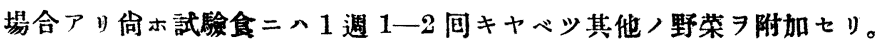

次 余ガ台ホ特二記載セント欲スル點ハ試驗食投與ト胃液探取トノ時間的關係ガ胃

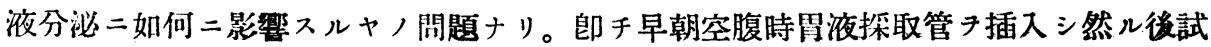
驗食キ投與七シ場合ハ既二上述セシ如クナレドモ最初二試驗食ク與へ次デ比較的二時

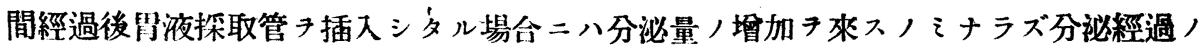
延長セラル、コトキ觀察セリ。例へバ一定試驗食キ投與後 2 時間乃至 4 時間ニシテ胃 液採取管插入スルヤ小胃內二貯溜セル胃液ハ直チ二流出ス。ソノ量試驗食投與ヨリ 胃管插入マデ，間二瘦孔ロヨリ自然落下七シ胃液量トキ合スルトキハ最初ヨリ胃管ヨ 插入シ採取シタル量ヨリモ多クノ場合蚟カニ大ナルキ知レリ. 分泌ノ少シク旺盛ナル 場合ハ小胃ハ胃液き以テ全ク充滿七リ．胃管キ插入スルヤ胃液ハ恰カモ瀧ノ如ク二落 下ス. ソノ量 $20 \mathrm{ccm}$. 又ハ $30 \mathrm{ccm}$. 于算ス. 斯カル場合ハ小胃內ノ貯溜胃液が排出七ラ レタル後ト雖ドモ分泌ハ頗ル旺ンニシテ丁度試驗食投與後 1 時間以內/最初ノ分泌時 期ニアルガ如シ．而シテ分泌ハ少ホ 2 時間乃至 3 時間以上モ持續ス。上述七シ現象八 犬ニ一定試驗食キ與へえレチ實驗用犬固定器二繋ガズ自由ノ姿勢キ取ラシメタル場合

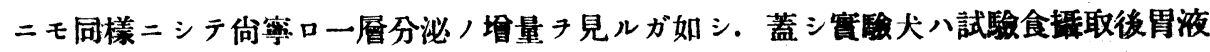

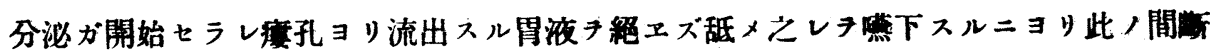




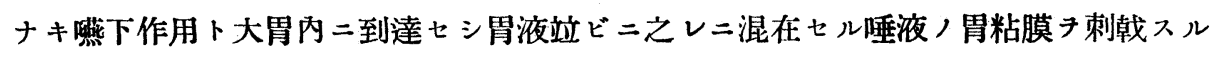
コト、ニヨリテ胃液, 分泌ガ一層鼓舞セラレ。䉆メ二小胃, 分泌モ同時二高マリ所謂 Circulus vitiosusートナリ分泌增量卜延長卜ヨ招來七シムルモノナラン。實驗大ョ シテ固定器臺二載七瘦孔部位丹䑛メシメザル場合分泌セラレタル胃液ハ一部分徐々二 落下シ排泄七ラルレドモ小胃內二八漸次胃液八貯溜シコ，胃液ガ小胃粘膜尹直接刺戟 シテ絕エズ小胃分泌フ鼓舞スルモノナラン。試驗食投與後ソノ倨犬子觀察スル二自由 ノ姿勢チトラシムルトキハ大多數二於テ何レモ瘦孔部位尹䑛メ。流出スル罗液ハえレ キ器下セルキ認ムレドモ稀二八瘦孔ニロキアテ小胃內二存在スル胃液キ吸引嘫下シ居

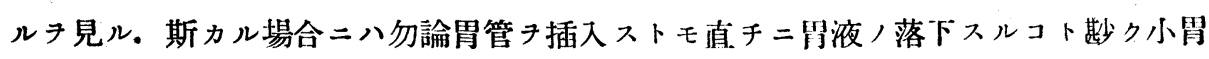
内八寧口空虚ニシテ斯カル場合ソ, 後ノ分泌モ明カ二微弱ナリ。少木試驗食投县沙後小 胃內二分泌セラレタル貯溜胃液八殊二夜間睡眠時ニ於テ再ビ胃粘膜す透シテ吸收セラ ル、モノナルコトチ知レリ。以上キ結論スレバ試驗食投與後一定時間經過後罥管キ插 入スル時ハ明カ二胃液分泌ハ高マル。 そレチ例示スレバ次ノ如シ。

賽驗例. 第 3 表。實驗大 Nr. 8. 褐黑占體重 21.200选 (19/I 1929 手術). 試驗食投與卜胃液 探取，時間的關係が胃液分泌二及ボス影響ヨ示セリ。手術後第 84 日目(12/IV 1929)，賽驗二於 テ、午前 10 時 0 分胃管习插入シ胃液, 分泌無キ 7 確入午前 10 時 30 分試驗食习投與シ 15 分每二 分割的二探取シタルニ午前 10 時 30 分ヨリ午後 4 時 30 分マデニ分泌セラレタル胃液總量 23.97 ccm.ナリ。次二手術後第 85 日目 (13/IV 1929)，賽驗二於テ八个前 10 時 0 分胃管习插入シ㖰液 八流出無キヨ見タル後胃管习拔キ去り午前 10 時 30 分試驗食习投與シソ，後大ヨシテ自由八姿

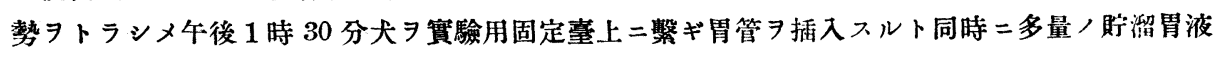
一時二流出セり.ソノ量 1 時 30 分ヨリ 45 分マデ= $23.0 \mathrm{ccm}$. ヨ算ス.ソノ後，分泌モ極メテ旺 盛ナリ. 午後 1 時 30 分ヨリ 4 時 30 分迄, 間二探取シタル冒液總量 $46.51 \mathrm{ccm}$. ナリ. 依ッテ前 日儿胃液量二比スル時八明カ二增量セルラ認ム。酸度八兩日，赛驗二於テ分泌量二站行シテ堽減 アリ而シテ後日，賽驗へ分泌量ノ增加アルガ故二酸度モ亦高シ. Pepsin 八反之分泌量，減少ス

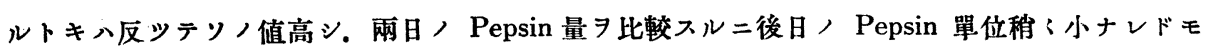
之レヨ分泌量卜對照シテ見ルトキの比較的二高值ヨ示セルガ如シ. 余八多數ノ犬ニッキ第 3 表二 示ス例二遭遇シ得タリ。

Pawlow 八唱ヘラレタル精神的胃液キ除キテハ胃液分泌八要スルニ種々，化學的物質 ニョリテ萑起七ラル、モノニシテ食物站ビニソノ消化分解產物. Hormone, biogene Amine, Pharmaka 等八其/有カナルモノニ屬スレドモ立二特記セントスルモノ八郎 手種々，消化液，胃液分泌二及ボス作用ナリ。Sokolow $(10)$ 八小胃瘦孔二隔離七ル大胃

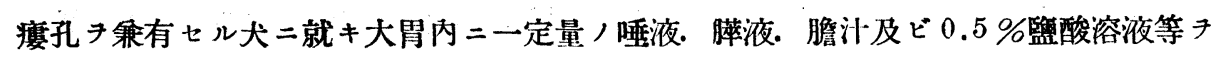
一定時間插入シ小胃ヨリ, 胃液分泌, 狀態ヲ檢查シ前三者二於テ特二著明ナル胃液分

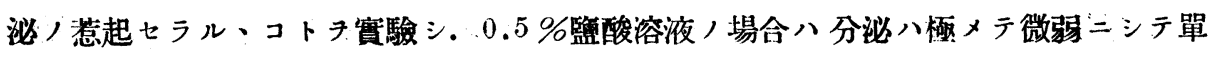


第 3 表 實驗大 Nr. 8 褐黑分體重 21.200 歼 (19/I 1929 手術) 試驗食投與卜 胃液探取卜／時間的關係が胃液分泌二及ボス影篦习示ス

\begin{tabular}{|c|c|c|c|c|c|c|c|c|c|}
\hline $\begin{array}{l}\text { 時日(12/IV1929) } \\
\text { 手術後第84日目 }\end{array}$ & $\begin{array}{c}\begin{array}{c}\text { 液量 } \\
\text { ccm. }\end{array} \\
\end{array}$ & \multicolumn{2}{|c|}{ 總酸度酸離監 } & Pepsin & $\begin{array}{l}\text { 嵵日 }(13 / \mathrm{IV1929)} \\
\text { 手術後第85日目 }\end{array}$ & \multicolumn{4}{|c|}{ 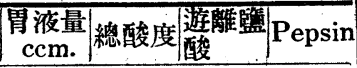 } \\
\hline $\begin{array}{ll}10 \mathrm{~b} & 0^{\prime} \text { 一胃管插入 } \\
10^{\mathrm{b}} & 0^{\prime}-15^{\prime}\end{array}$ & $\begin{array}{c}0.10 \\
(\text { 粘液) }\end{array}$ & & & & \multicolumn{5}{|c|}{$10 \mathrm{~b} 30^{\prime}$ a.m. 試驗食投與 } \\
\hline $10^{\mathrm{h}} 15^{\prime}-30^{\prime}$ & 0 & & & & \multicolumn{5}{|c|}{$1^{h} 30^{\prime}$ p.m. 胃管插入卜同時二多量，貯溜 } \\
\hline \begin{tabular}{|l|}
$10^{\mathrm{h}} 30^{\prime}$ 試驗食投與 \\
$10^{\mathrm{h}} 30^{\prime}-45^{\prime}$
\end{tabular} & 2.10 & \multirow{4}{*}{143.8} & \multirow{4}{*}{136.5} & \multirow{4}{*}{960} & \multirow{2}{*}{\multicolumn{2}{|c|}{ 胃液ヨ一時二探取 }} & & & \\
\hline $10^{\mathrm{h}} 45^{\prime}-11^{\mathrm{h}} 0^{\prime}$ & 3.63 & & & & & & & & \\
\hline $11^{\mathrm{h}} 0^{\prime}-15^{\prime}$ & 0.92 & & & & $1^{\mathrm{h}} 30^{\prime}-45^{\prime}$ & 23.0 & \multirow{4}{*}{146.2} & \multirow{4}{*}{138.5} & \multirow{4}{*}{960} \\
\hline $11^{\mathrm{h} 15^{\prime}-30^{\prime}}$ & 0.68 & & & & $1^{\mathrm{h}} 45^{\prime}-2^{\mathrm{h}} 0^{\prime}$ & 1.80 & & & \\
\hline $11^{11} 30^{\prime}-45^{\prime}$ & 0.60 & \multirow{4}{*}{138.8} & \multirow{4}{*}{131.2} & \multirow{4}{*}{1440} & $2^{\mathrm{h}} 0^{\prime}-15^{\prime}$ & 1.04 & & & \\
\hline $11^{\mathrm{h}} 45^{\prime}-0^{\mathrm{h}^{\prime}}$ & 0.45 & & & & $2 \mathrm{~h} 15^{\prime}-30^{\prime}$ & 1.05 & & & \\
\hline $0^{\mathrm{h}} 0^{\prime}-15^{\prime}$ & 1.05 & & & & $2 \mathrm{~h} 30^{\prime}-45^{\prime}$ & 1.95 & \multirow{4}{*}{141.5} & \multirow{4}{*}{134.4} & \multirow{4}{*}{1440} \\
\hline $0^{\mathrm{b}} 15^{\prime}-30^{\prime}$ & 0.55 & & & & $2 \mathrm{~h} 45^{\prime}-3 \mathrm{~b} 0^{\prime}$ & 1.34 & & & \\
\hline $0^{\mathrm{h}} 30^{\prime}-45^{\prime}$ & 0.48 & \multirow{4}{*}{126.5} & \multirow{4}{*}{120.8} & \multirow{4}{*}{1920} & $3^{\mathrm{h}} 0^{\prime}-15^{\prime}$ & 2.00 & & & \\
\hline $0^{\mathrm{h}} 45^{\prime}-1 \mathrm{~h} 0^{\prime}$ & 0.45 & & & & $3 \mathrm{n} 15^{\prime}-30^{\prime}$ & 2.00 & & & \\
\hline $1^{\text {h }} 0^{\prime}-15^{\prime}$ & 0.35 & & & & $3^{\mathrm{b}} 30^{\prime}-45^{\prime}$ & 2.40 & \multirow{4}{*}{144.2} & \multirow{4}{*}{138.1} & \multirow{4}{*}{960} \\
\hline $1^{\mathrm{h}} 15^{\prime}-30^{\prime}$ & 0.42 & & & & $3 \mathrm{~h} 45^{\prime}-4 \mathrm{~h} 0^{\prime}$ & 3.63 & & & \\
\hline $1^{\mathrm{h}} 30^{\prime}-45^{\prime}$ & 0.53 & \multirow{4}{*}{127.8} & \multirow{4}{*}{121.4} & \multirow{4}{*}{1920} & $4^{\mathrm{b}} \quad 0^{\prime}-15^{\prime}$ & 3.10 & & & \\
\hline $1^{\mathrm{h} 45^{\prime}-2 \mathrm{~h} 0^{\prime}}$ & 0.62 & & & & $4^{\mathrm{h} 15^{\prime}-30^{\prime}}$ & 3.20 & & & \\
\hline $2^{\mathrm{h}} 0^{\prime}-15^{\prime}$ & 0.46 & & & & $1^{1} 30^{\prime}-4^{\mathrm{h}} 30^{\prime}$ & 含計 & & & \\
\hline $2^{\mathrm{h}} 15^{\prime}-30^{\prime}$ & 0.64 & & & & & & & & \\
\hline $2^{n} 30^{\prime}-45^{\prime}$ & 0.75 & \multirow{4}{*}{138.3} & & & & & & & \\
\hline $2 \mathrm{~b} 45^{\prime}-3 \mathrm{~h} 0^{\prime}$ & 0.74 & & 130.3 & 1440 & & & & & \\
\hline $3^{\mathrm{h}} 0^{\prime}-15^{\prime}$ & 0.81 & & & & & & & & \\
\hline $3^{\mathrm{h}} 15^{\prime}-30^{\prime}$ & 0.97 & & & & & & & & \\
\hline $3^{\mathrm{b}} 30^{\prime}-45^{\prime}$ & 1.56 & & & & & & & & \\
\hline $3^{\mathrm{h}} 45^{\prime}-4^{\prime \prime 0^{\prime}}$ & 1.72 & 141.2 & 134.8 & 960 & & & & & \\
\hline $4^{11} \quad 0^{\prime}-15^{\prime}$ & 1.84 & & & & & & & & . \\
\hline $4^{\prime} 15^{\prime}-30^{\prime}$ & 1.65 & & & & & & & & \\
\hline $\begin{array}{l}10^{\mathrm{h}} 30^{\prime}-4^{\mathrm{b}} 30^{\prime} \\
\text { a.m. p.m. }\end{array}$ & $\begin{array}{l}\text { 合計 } \\
23.97\end{array}$ & & & & & & & & \\
\hline
\end{tabular}

二水丹用ヒタル場合ト比較セシ結果案口抑制セラレタリト論ジ居レトモ之ハ比較的濃 厚ナル液チー時二多量插入セシ結果ナラント思惟セラル. Frouin ${ }^{(11)(12)} モ$ 办唾液ガ胃液 分泌キ催進セシムルコトフ述ベ少ホ又中和胃液ガ胃液分泌キ濙起七シムルコト實驗シ 胃液中二胃液分泌催進性作用物質, 存在丹認メタリ而シテ之レキ酵素ノ作用二ハ非ズ トナ七リ．余モ亦中和罠液，胃液分泌作用認メタレドモりノ有效物質ノ何物ナリヤ

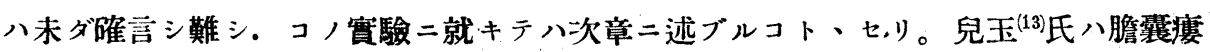
ヨ有スル犬二就キ流出スル膽计タ採取セズシテ犬ョシテ自由ニえレチ䑛メシメタルト キハ翌日ノ脆汁分泌量ノ增加アルタ認メタリ。余ノ實驗犬二於テモ連日ノ胃液採取き 


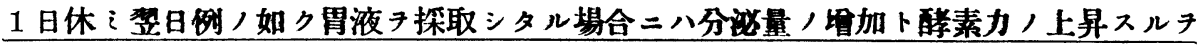

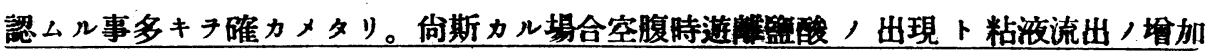

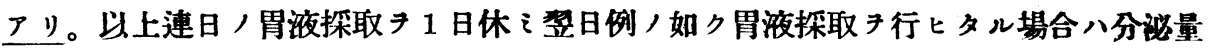
ノ增加アリ。之レチ例示スレバ次ノ如シ。

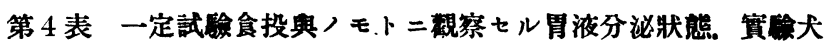
5 頭ノ本均成績(何 $レ モ$ 手術後 3 週間經過後，賽除）

\begin{tabular}{|c|c|c|c|c|c|c|c|c|c|c|}
\hline \multirow[b]{2}{*}{ 時 } & \multicolumn{5}{|c|}{$\begin{array}{l}\text { 蓮日胃液探取 } \text { ヨ續ケ最後日二探取 } \\
\text { 七ル埸合 }\end{array}$} & \multicolumn{5}{|c|}{ 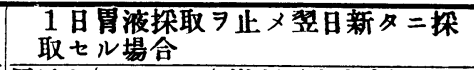 } \\
\hline & $\begin{array}{c}\text { 胃液量 } \\
\text { ccm. }\end{array}$ & 總酸度 & \begin{tabular}{|l|} 
游離 \\
篮酸
\end{tabular} & 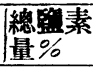 & Pepsin & $\begin{array}{l}\text { 胃液量 } \\
\text { ccm. }\end{array}$ & 總酸度 & 遊離 & $\mid \begin{array}{l}\mid \text { 總監素 } \\
\mid \text { 量\% }\end{array}$ & Pepsin \\
\hline $\begin{array}{c}8 \mathrm{~h} 0^{\prime}-9 \mathrm{~h}^{\prime} \\
\text { a.m. }\end{array}$ & $\mid \begin{array}{c}0.95 \\
(\text { (粘液) }\end{array}$ & & $\left|\begin{array}{c}\text { Congo } \\
(-)\end{array}\right|$ & & & $\begin{array}{c}1.75 \\
(\text { (粘液) }\end{array}$ & & $\begin{array}{c}\text { Congo } \\
(+)\end{array}$ & & \\
\hline $\begin{array}{l}9 \mathrm{~h} 0^{\prime} \text { 試铪晨投興 } \\
9 \mathrm{~h} 0^{\prime}-15^{\prime}\end{array}$ & 0.75 & \multirow[t]{2}{*}{120.4} & \multirow[t]{2}{*}{110.8} & \multirow[t]{2}{*}{0.55} & \multirow[t]{2}{*}{720} & 1.05 & \multirow[t]{2}{*}{137.5} & \multirow[t]{2}{*}{120.5} & \multirow[t]{2}{*}{0.59} & \multirow{2}{*}{1440} \\
\hline $9^{\mathrm{h}} 15^{\prime}-30^{\prime}$ & 1.78 & & & & & 2.10 & & & & \\
\hline $9^{\mathrm{h}} 30^{\prime}-45^{\prime}$ & 1.05 & \multirow{2}{*}{118.6} & \multirow{2}{*}{109.8} & \multirow{2}{*}{0.56} & \multirow{2}{*}{1050} & 1.80 & \multirow{2}{*}{128.5} & \multirow{2}{*}{113.9} & \multirow{2}{*}{0.57} & \multirow{2}{*}{1920} \\
\hline $9^{\mathrm{h}} 45^{\prime}-10^{\mathrm{h}} 0^{\prime}$ & 0.35 & & & & & 0.52 & & & & \\
\hline $10^{\mathrm{b}} 0^{\prime}-15^{\prime}$ & 0.20 & \multirow{4}{*}{103.6} & \multirow{4}{*}{84.4} & \multirow{4}{*}{0.55} & \multirow{4}{*}{1400} & 0.25 & \multirow{4}{*}{110.5} & \multirow{4}{*}{92.3} & \multirow{4}{*}{0.55} & \multirow{4}{*}{1560} \\
\hline $10^{\mathrm{h}} 15^{\prime}-30^{\prime}$ & 0.10 & & & & & 0.15 & & & & \\
\hline $10^{\mathrm{h}} 30^{\prime}-45^{\prime}$ & 0.15 & & & & & 0.10 & & & & \\
\hline $10^{\mathrm{h}} 45^{\prime}-11^{\mathrm{h}} 0^{\prime}$ & 0.30 & & & & & 0.25 & & & & \\
\hline $11^{\mathrm{h}} 0^{\prime}=15^{\prime}$ & 0.20 & \multirow{4}{*}{108.7} & \multirow{4}{*}{83.3} & \multirow{4}{*}{0.57} & \multirow{4}{*}{1250} & 0.35 & \multirow{4}{*}{116.3} & \multirow{4}{*}{96.5} & \multirow{4}{*}{0.57} & \multirow{4}{*}{1930} \\
\hline $11^{\mathrm{h}} 15^{\prime}-30^{\prime}$ & 0.35 & & & & & 0.40 & & & & \\
\hline $11^{\mathrm{h}} 30^{\prime}-45^{\prime}$ & 0.45 & & & & & 0.45 & & & & \\
\hline $11^{\mathrm{h}} 45^{\prime}-0 \mathrm{~b} 0^{\prime}$ & 0.40 & & & & & 0.50 & & & & \\
\hline
\end{tabular}

賽驗例。第 4 表。一定試驗会投與ノモト二觀察セル胃液分泌狀態/戀化ヨ示セリ。郎千賽驗小胃 犬ヨシテ日常起居。運動。試驗食. 胃液探取時間及ビ睡、讯等习略?一定トシ。一定ノ探取條作ノモ ト二大凡 1 週間連日胃液ヨ探取フルニ第 1 日目八空腹時 1 時間/粘液流出量最モ多量ナル 7 認 么試驗食投與後假り $=3$ 時間, 胃液量 $ᄏ$ 比較スルニ第 1 日目八胃液量八概シテ最モ多量ナルモ 稍?牛數二於テ第 2 日目乃至八第 3 日目二於テ最モ多量ナルコトアリ第 4 日目以後八稍 : 減量 レドモソ，後ノ分泌量二八變動比較的小トナルが如シ。第 7 日目又八第 8 日目二1回胃液探取 7 止メ犬ヨシテ自由/姿勢ヨ取ラシメ。唯試驗食へ本日通り之レヨ興フルコト、シ次二翌日即手第 8 日目又八第 9 日目二新タ二本日通り試驗食ヨ投興シ胃管ニョリ胃液ヨ探取スルニ第 1 日又八 第 2 日目二於ヶルが如ク明力二分泌量，增加セルヨ認ム。之レヨ最後ノ郎キ 2 日前，探取量卜比 較スルトキハ多ク，場合分泌量，增加卜酸度，上昇习來スコトヨ知ル。殊二表中二モ明カナル如 ク空腹時粘波，增量アリ。佾木 Pepsin 量モ分泌量，增量セルニモ拘ハラブ反ッテ上昇セリ。

以上ノ事實ヨリ余八分泌七ラレタル消化液八互二他，消化液，分泌子催進セシムルト 同時二自己/腺細胞テ刺戟シソ/分泌テ鼓舞セシムルモノナラント思惟ス. 殊二消化 管內二分泌七ラレタル消化液ハ再ビ吸收セラレ更二自己腺細胞二到達シ之レガ分泌機 態二關與スルモノナラン。えレチ宫川教授ノ直接作用說ニョリテ說明スルコトチ得べ シ。而シテ胃液ニアリテハ之レガ腸ニ移り一定，變化き蒙りタル後腸壁ヨリ再ビ吸收 セラレそレガ一部分胃腺細胞二到達スルコトハ容易二想像シ得ラル、所ニシテソノ機 能二關興スル因子トシテハ Chlor ガ其ノ1ッニ數へラルベキモノナルコトハ帠監酸 
分泌二關スル Boenheim ${ }^{(14)}$ ）說ニョリテモ明暸ナル事宾ニシテ. 佾木 Rosemann ${ }^{(15)}$ ，

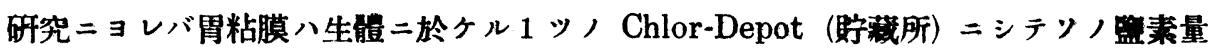
八重量百分率二於テ生能，監素量 $(0.1967-0.2158 \%)=$ 比シ造カ二大二シテ血液站ビ 二皮膚卜比較スルトキハ犬ノ空腹時二於テ八血液 $0.3270 \%$. 皮虔 $0.2865 \%$. 因粘膜 $0.3389 \%$ \%レ゙モ姛料フ興へタル時八血液 $0.3079 \%$. 皮膚 $0.2519 \%$. 胃粘膜 0.268

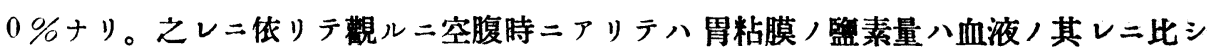
テ大ナレドモ消化時ニアリテハ此，關係八正反對ナリ. 而シテ血液. 皮唐. 胃粘膜， 三者何レモ消化時郎于胃液分泌時二於テ監素量，減少チ示七リ．殊二胃粘膜二於ケル

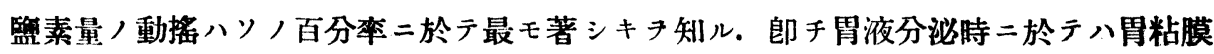
内, Chlor 八最モ多ク矢ハレ次二胃液分泌が止に腸二於ケル消化吸收茂行ハル、二 至レバ胃粘膜內，Chlor，增量シ Chlor，沈著キ來三百分率二於テ三者中ノ最大值

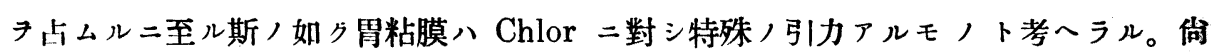
木胃腺機能二關與スル因子トシテハ鲎然 Pepsin 及ビ其ノ他/胃酵素ガ考へラルべキ モノニシテ一旦消化液トシテ分泌セラレタル酵素八必ズ破壞セラル、ニセヨ之レガ何 等力，形二於テ腸粘膜 $コ$ り吸收七ラレ一部分八再ビ胃腺細胞二到達シ此處二於テ絶エ ズ Pepsin 新生二利用セラル、モノナラン。乃至ハPepsin 腺二對シ或種ノ刺戟トナ

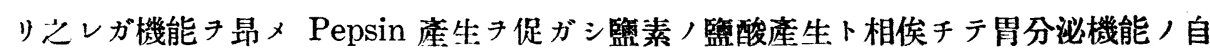
家調篮作用ガ行ハル、モノナラン。

\section{第四莗 中和整液注入兴羷}

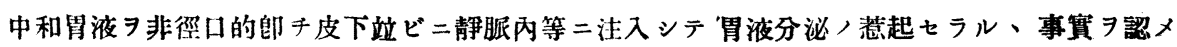

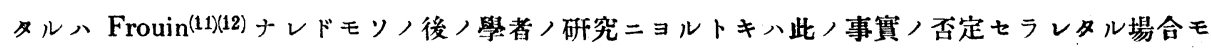

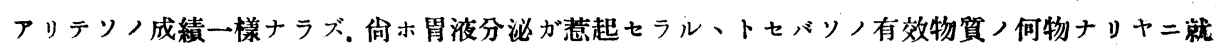

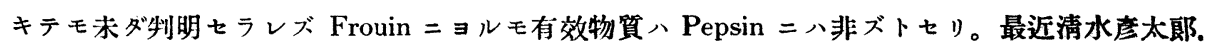
松井董作雨氏 ${ }^{(16)}$ 八毫繁學雜誌二於テ胃液，静脈內及ビ 皮下注射ニョル胃液分泌作用ナル題目

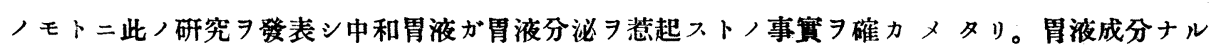

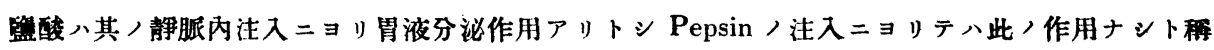

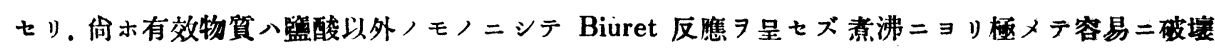
七ラレッ>耐熱能力八 $80^{\circ} \mathrm{C}$ 加熱 30 分間內外ニアリトンAtropinニヨリ完全二阻止七ラル、等 ，事實 $コ$ Histamin, Gastrin或八胃粘膜抽出液卜八全ク異レル物質ナリト結論セり。Luckhardt,

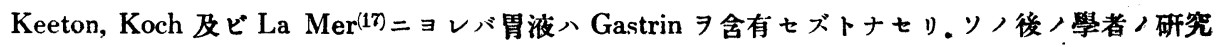
ニョルモ胃液中二 Gastrin 八存在セザルモ, 、如シ。余八前章二於テ述ベタルが如ク分泌セラレ タル胃波ヘ之レガ體外二排除セラレザル限り再ビ消化管ヨリ吸收セラレテ之が自己腺細胞二到

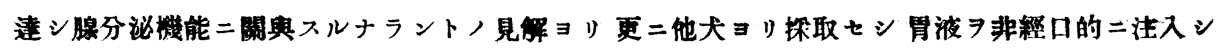


胃液分泌二對シ如何程ノ影響アルモノナリヤク檢セントシテ本賽驗ニ渚手セリ。

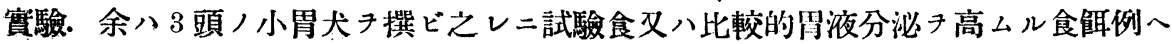
バ馬肉.ビスケット等キ與へテ成ルベク多量ノ純粹胃液き短時間内二集メ直チニえレ

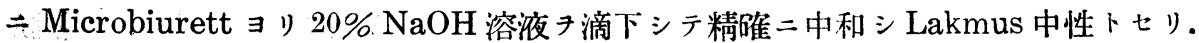

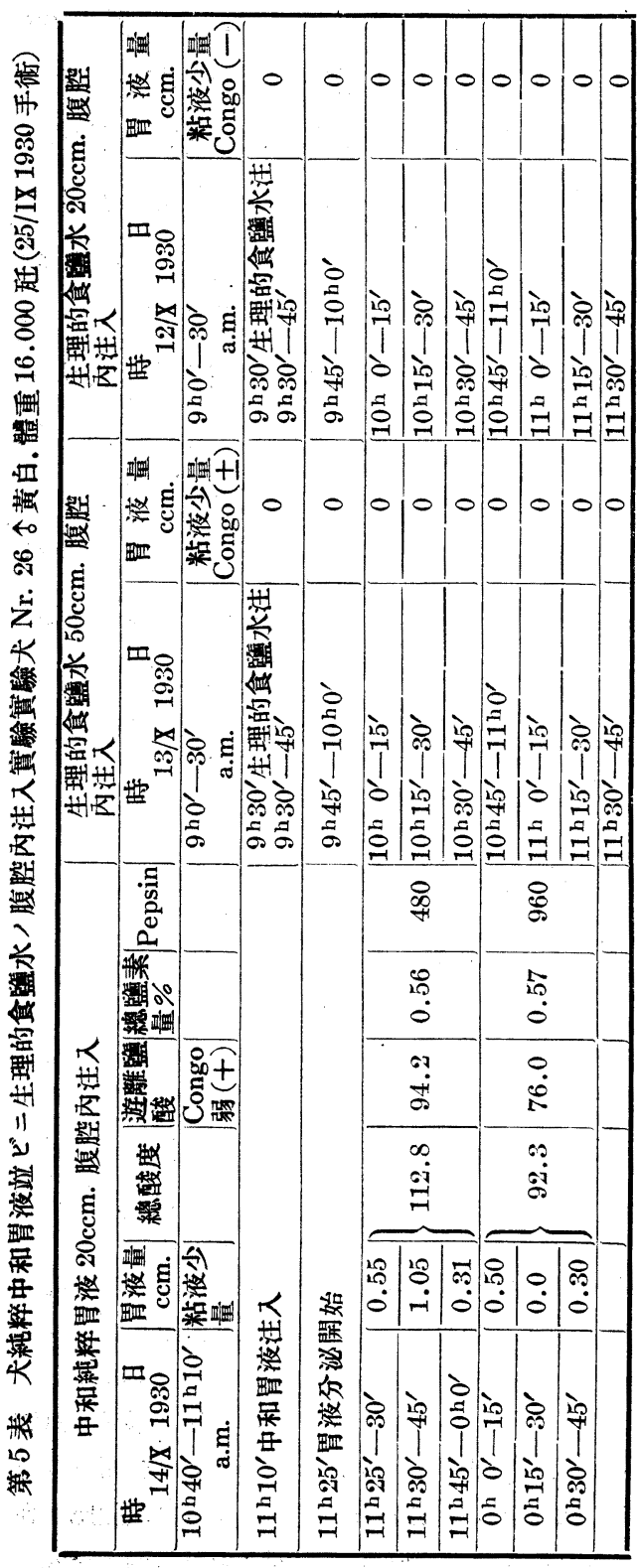

カ、ル場合中和二要スル $\mathrm{NaOH}$ 液量 八荊液量， $1 / 20$ 以下二テ足ルコト、 ナル。 カ、ル中和胃液, Chlor 量八大 凡 $0.55 \%$ 內外ナリ。

以上調製七ル中和罗液卡，體重 pro Kilo $1.0^{\circ} \mathrm{ccm}$. 八割合二動物，腹 犋內二注射七シ二大凡 15 分前後二於 テ分泌儿開始セラル、キ實驗セリ。ソ ，後，分泌持縝時間八 1 時間內外 =シ テ比較的二短カシ.コノ量ヨりモ透カ 二少量郎于體重 pro Kilo $0.5 \mathrm{ccm}$. 以 下二於テ八敏常確實二分泌子惹起七シ $ム ル \ni$ 得ズ. Frouin ${ }^{\left.(1)^{\prime} 12\right)}$ 八, ,estomac séquestré”，犬ニツキテ實驗セシ成 績ニョレバ $40 \mathrm{ccm} . ＼mathrm{~ ， 中 和 沼 液 き 皮 下 ~}$

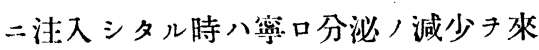
シ 1 日本均 $300 \mathrm{ccm}$. ガ $160 \mathrm{ccm}$. トナ リタリト稱シ。コノ減少八注入後 48 時間二於テ少木證明七ラレ $120 \mathrm{ccm}$. 以 上，分泌キ見ザリキ。酸度㕸ビ二消化 力キ減少七シガ數日ニシテ分泌八恢復 シ數日間八寜口增量チ來シタリト稱七 リ. 次二 $100 \mathrm{ccm}$.，胃液子皮下二注射 七シニ 1 日，本均分泌量 $300 \mathrm{ccm}$. カ $560 \mathrm{ccm}$. 二增加七り卜稱七り. 清水. 松井 ${ }^{(16)}$ 兩氏／靜脈內及ビ皮下注射賽驗 成績 見ルニ余，使用量 $コ リ モ$ 比較的 
少量ニテ著明ノ上昇テ來セルガ如シ。次二余ハ對照トシテ假り二生理的食監水ヲ實驗 犬八腹腔內二注入七シニ犬ノ體重 pro Kilo $1.0 \mathrm{ccm}$. 及ビ $2.0 \mathrm{ccm}$. キ使用スルモ毫モ

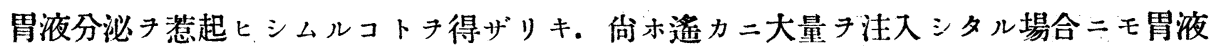

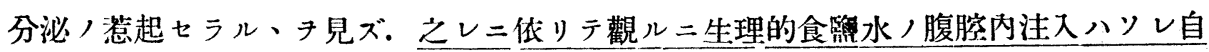
身胃液ノ分泌キ惹起七シムルコト能ハザルモノト思惟ス。但シ余ノ經驗二徵スルモ早 朝空腹時先ヅ生理的食覧水, 上記使用量, 2 倍以上キ犬ノ腹腔內二注入シ置キ然ル後 一定試驗食チ本常通り投與シタル場合ニ八生理的食監水キ注入セザリシ場合二比シ分 泌量八時二明カニ大トナルコトアルチ認メタリ。

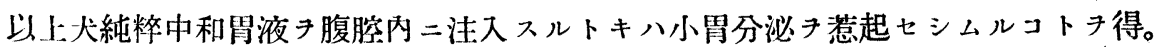
そレキ例示スレバ次ノ如シ。

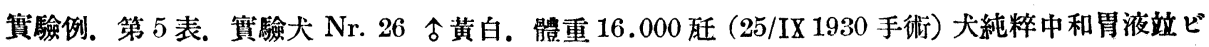
二生理的食監水, 腹腔內注入锤驗 模樣 見タル後 $11^{\mathrm{h}} 10^{\prime}$ ，中和胃液 $20 \mathrm{ccm}$. $尹$ 腹腔内二注入. $11^{\mathrm{h}} 2 \mathrm{a}^{\prime}$ 分泌，開始セラレタル

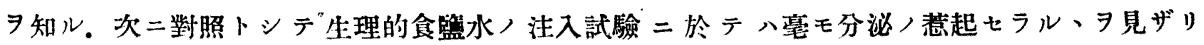
キ。

第 6 表 大純粹中和胃液, 腹腔內注入試驗。賽驗大 Nr. 29 合茶白. 體重 15.250䣶(14/XI 1930手術)

\begin{tabular}{|c|c|c|c|c|c|c|}
\hline \multicolumn{5}{|c|}{ 中和純粹胃液 $30 \mathrm{ccm}$. 腹腔內注入 } & \multicolumn{2}{|c|}{ 加然中和胃液 $30 \mathrm{ccm}$. 注入 } \\
\hline $\begin{array}{cc}\text { 時 } & \text { 日 } \\
30 / \mathrm{XI} & 1930\end{array}$ & $\begin{array}{c}\text { 胃液量 } \\
\text { ccm. }\end{array}$ & 總酸度 & 遊離住監 & Pepsin & $\begin{array}{cc}\text { 時 } & \text { 日 } \\
31 / \text { XII } & 1930\end{array}$ & $\begin{array}{c}\text { 胃液量 } \\
\text { ccm. }\end{array}$ \\
\hline $\begin{array}{c}3^{\mathrm{h}} 45^{\prime}-4^{\mathrm{b}} 15^{\prime} \\
\text { p.m. }\end{array}$ & $\begin{array}{c}0.25 \\
\text { (粘液) }\end{array}$ & & & & $\begin{array}{c}4^{\mathrm{b}} 0^{\prime}-30^{\prime} \\
\text { p.m. }\end{array}$ & $\begin{array}{c}0.43 \\
\text { 粘 } \text { 液 }\end{array}$ \\
\hline \multicolumn{5}{|c|}{$4^{\mathrm{h}} 15^{\prime}$ 中和胃液注入 } & \multicolumn{2}{|c|}{$4^{\mathrm{h}} 30^{\prime}$ 加熱中和胃液注入 } \\
\hline \multicolumn{5}{|l|}{$4 h 28^{\prime}$ 分泌開始 } & $4^{\mathrm{h}} 30^{\prime}-45^{\prime}$ & 0 \\
\hline $4 \mathrm{~h} 28^{\prime}-45^{\prime}$ & 1.15 & \multirow{4}{*}{118.5} & \multirow{4}{*}{104.2} & \multirow{4}{*}{960} & $4^{\mathrm{h}} 45^{\prime}-5^{\mathrm{h}} 0^{\prime}$ & 0 \\
\hline $4 \mathrm{~h} 45^{\prime}-5^{\mathrm{h}} 0^{\prime}$ & 0.53 & & & & $5^{\mathrm{h}} 0^{\prime}-15^{\prime}$ & 0 \\
\hline $5^{\text {h }} 0^{\prime}-15^{\prime}$ & 0.30 & & & & $5^{\mathrm{h}} 15^{\prime}-30^{\prime}$ & $\begin{array}{l}\text { 少量粘液 } \\
\text { Congo }(-)\end{array}$ \\
\hline $5^{h} 15^{\prime}-30^{\prime}$ & 0.05 & & & & $5^{\mathrm{h}} 30^{\prime}-45^{\prime}$ & 0 \\
\hline 5 h $30^{\prime}--45^{\prime}$ & 0.0 & & & & $5^{\mathrm{b}} 45^{\prime}-6^{\mathrm{h}} 0^{\prime}$ & \begin{tabular}{|c} 
少量粘液 \\
Congo $(+)$
\end{tabular} \\
\hline $5 \mathrm{~h} 45^{\prime}-6 \mathrm{~h} 0^{\prime}$ & 0.0 & & & & & \\
\hline
\end{tabular}

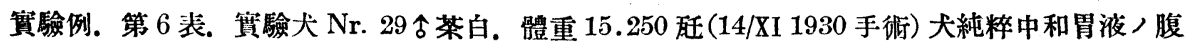
腔內注入試驗成績 $4^{\mathrm{h}} 15^{\prime}$ 中和胃波 7 注入シ $4 \mathrm{~h} 28^{\prime}$ 分泌，開始セラレタル 知ル。ソ，後，分泌持續時間約 1 時間

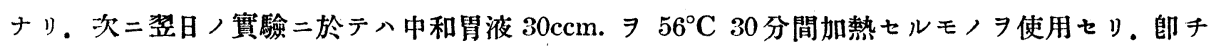

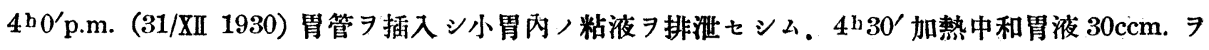
腹腔內二注入セシニ其, 後何等分泌, 意起セラレショ認メプ。 
第 7 表 中和胃液腹脱內注入

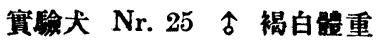
14.300㕵 $(26 / \mathrm{VW} 1930$ 手術)

中和胃液 $7.0 \mathrm{ccm}$. 注入

\begin{tabular}{|c|c|}
\hline $\begin{array}{cc}\text { 時 } & \text { 日 } \\
18 / \mathrm{X} & 1930\end{array}$ & $\begin{array}{l}\text { 胃 液 量 } \\
\text { ccm. }\end{array}$ \\
\hline $\begin{array}{c}11^{\mathrm{h}} 0^{\prime}-30^{\prime} \\
\text { a.m. }\end{array}$ & $\begin{array}{l}0.35 \\
\text { 粘液 }\end{array}$ \\
\hline $\begin{array}{l}11 \mathrm{~h} 30^{\prime} \text { 中和胃液注入 } \\
11^{\mathrm{h}} 30^{\prime}-45^{\prime}\end{array}$ & 0 \\
\hline $11^{\mathrm{h}} 45^{\prime}-0^{\mathrm{h}} 0^{\prime}$ & 0 \\
\hline $0^{\mathrm{h}} 0^{\prime}-15^{\prime}$ & 0 \\
\hline $0 \mathrm{~h} 15^{\prime}-30^{\prime}$ & 少量粘液 \\
\hline $0^{\mathrm{h}} 30^{\prime}-45^{\prime}$ & 0 \\
\hline $0 \mathrm{~h} 45^{\prime}-1 \mathrm{~h}^{\prime} 0^{\prime}$ & 少量粘液 \\
\hline
\end{tabular}

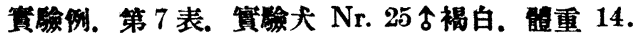
300 硅。（26/V四 1930手術)。1 $11^{\mathrm{b}} 30^{\prime}(18 / \mathrm{X} 1930)$ 中和胃 液 $7.0 \mathrm{ccm}$. $\rightarrow$ 腹腔內 $=$ 注入七シニソ, 後分泌，開始 セラレタルヨ見ブ。之レ比較的少量 7 注入セシがタ メナラン。

次 $=$ Pepsin. 溶液ノ注入試驗成績 見ルニ余 八先ヅ隇菌蒸餾水ニ Pepsin-Merck キ加へテソ ノ $0.1 \%$. 1.0\%. 5.0\%. 10\%等夫々使用，際 新鮮ナルモノチ調製シえレチ動物ノ皮下端ビニ 腹腙內二注入キ試 $゙$ タ。今 $0.1 \%$ 乃至 $1.0 \%$ Pepsin 溶液 丹體重 pro Kilo $1.0 \mathrm{ccm}$. 動物

皮下站ビ二腹腔內二注入スルニ每常何等分泌タ告起セシムルキ得ザリキ。又試驗食投 興二先ンジテコノ量キ注入スルモ概シテ分泌/增量乃至八Pepsin力ノ上昇スルチ認 メ難シ. 更二 $5.0 \%$ 乃至 $10.0 \%$ 溶液キ腹腔內二注入シタル場合二モ殆ンド分泌ノ聕 起七ラル、コト無シ。余ノ檢查二於テハPepsin-Merck，10\%溶液八犬純粹胃液， Pepsin 力二相當セルォ認メタリ。郎千該溶液 $1.0 \mathrm{ccm}$. /有スルPepsin 單位 640 二 1280 ナリ。次二 $10 \%$ 溶液キ連日 10 日間以上二瓦り注入キ續クルトキハ胃液分泌八 多少艺進セルガ如キ傾向キ示セリ。然レドモ上述セシ如クPepsin 溶液自身二八分泌 催進性作用八存在セザルモノ、如シ。

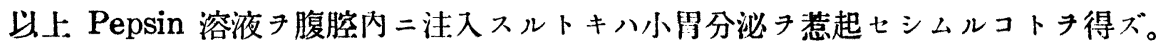
そレォ例示スレバ次ノ如シ。

第 8 表 Pepsin 液, 腹腔內注入實驗。實驗犬 Nr. 29 令茶白. 體重 15.250 歼 (14/XI 1930 手術)

\begin{tabular}{|c|c|c|c|}
\hline \multicolumn{2}{|c|}{$5 \%$ Pepsin 液 15cc. 腹腔內注入 } & \multicolumn{2}{|c|}{ 10\% Pepsin 液 15cc. 腹腔內注入 } \\
\hline $\begin{array}{c}\text { 時 } \\
17 / \mathrm{XII}\end{array}$ & $\begin{array}{c}\text { 液 } \\
\text { ccm. 量 }\end{array}$ & $\begin{array}{l}\text { 時 } \\
18 / \text { XII }\end{array}$ & $\begin{array}{c}\text { 胃 液 量 } \\
\text { ccm. }\end{array}$ \\
\hline $10^{\mathrm{b}} 25^{\prime}-45^{\prime}$ & 少量粘液 & $10^{\mathrm{h}} 30^{\prime}$ 胃管插入 & \\
\hline $10 \mathrm{~h} 45^{\prime}-11 \mathrm{~h} 0^{\prime}$ & 0 & $10^{\mathrm{h}} 35^{\prime}$ Pepsin 注 & \\
\hline \multicolumn{2}{|l|}{$11^{\mathrm{h}} 0^{\prime}$ Pepsin 注入 } & $10^{\mathrm{h}} 35^{\prime}-45^{\prime}$ & 0 \\
\hline $11^{\mathrm{h}} 0^{\prime}-15^{\prime}$ & 0 & $10^{\mathrm{h}} 45^{\prime}-11^{\mathrm{h} 0^{\prime}}$ & \multirow[b]{2}{*}{0.1} \\
\hline $11^{\mathrm{h}} 15^{\prime}-30^{\prime}$ & $\begin{array}{c}\text { 少量粘液 } \\
\text { Congo 弱 }(+)\end{array}$ & $11^{\mathrm{h}} 0^{\prime}-15^{\prime}$ & \\
\hline $11^{\mathrm{b}} 30^{\prime}-45^{\prime}$ & 0 & $11^{\mathrm{h}} 15^{\prime}-30^{\prime}$ & 0 \\
\hline $11^{\mathrm{h}} 45^{\prime}-0^{\mathrm{h}} 0^{\prime}$ & 0 & $11^{\mathrm{h}} 30^{\prime}-45^{\prime}$ & 少量粘液 \\
\hline $0^{h} 0^{\prime}-30^{\prime}$ & 少量粘液 & $11^{\mathrm{h} 45^{\prime}-0^{\mathrm{h}} 0^{\prime}}$ & 0 \\
\hline
\end{tabular}

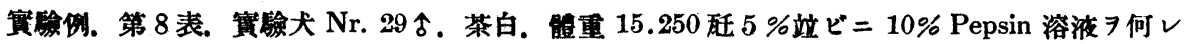
モ $15.0 \mathrm{ccm}$. 宛腹腔內二注入セシニ殆ンド分泌アルヨ認メズ。 


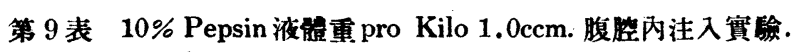
9h15'a.m. 注入.

\begin{tabular}{|c|c|c|c|}
\hline \multicolumn{4}{|c|}{ Nr. 26 令體重 16.000 咶 25/1X 1930 手術 } \\
\hline $\begin{array}{cc}\text { 時 } & \text { 日 } \\
29 / \mathrm{X} & 1930\end{array}$ & $\begin{array}{c}\text { 胃液 量 } \\
\mathrm{ccm} .\end{array}$ & $\begin{array}{c}\text { 日 } \\
1930\end{array}$ & $\begin{array}{c}\text { 胃液 量 } \\
\mathrm{ccm} .\end{array}$ \\
\hline $\begin{array}{c}8^{\mathrm{h}} 30^{\prime}-9 \mathrm{~h} 0^{\prime} \\
\text { a.m. }\end{array}$ & $\begin{array}{c}0.48 \\
\text { (粘液) }\end{array}$ & $10^{\mathrm{h}} 15^{\prime}-30^{\prime}$ & 0 \\
\hline $9 \mathrm{~h} 0^{\prime}-15^{\prime}$ & $\begin{array}{l}0.15 \\
(. .)\end{array}$ & $10^{\mathrm{h}} 30^{\prime}-45^{\prime}$ & $\begin{array}{c}0.25 \\
\text { (粘液) }\end{array}$ \\
\hline $9^{\mathrm{b}} 15^{\prime}-30^{\prime}$ & $\begin{array}{c}0.10 \\
\text { Congo }(t)\end{array}$ & $10^{\mathrm{h}} 45^{\prime}-11^{\mathrm{h}} 0^{\prime}$ & 0 \\
\hline $9 \mathrm{~h} 30^{\prime}-45^{\prime}$ & $\begin{array}{c}0.15 \\
\text { Congo }(t)\end{array}$ & $11^{\mathrm{h}} 0^{\prime}-15^{\prime}$ & $\begin{array}{c}0.14 \\
(\text { 粘液 }) \\
\end{array}$ \\
\hline $9^{\mathrm{h}} 45^{\prime}-10^{\mathrm{h}} 0^{\prime}$ & 0 & $11^{\mathrm{h}} 15^{\prime}-3 \mathrm{o}^{\prime}$ & 0 \\
\hline $10^{\mathrm{h}} 0^{\prime}-15^{\prime}$ & 少量粘液 & $11 \mathrm{~h} 30^{\prime}-45^{\prime}$ & 少量粘液 \\
\hline
\end{tabular}

實悘洌. 第 9 表。 實驗大 Nr. 26 占 黄白. 體重. 16.000 程 $8^{\mathrm{b}} 30^{\prime}$ 'a.m. (29/X 1930）胃管插入粘 液入流出アリ。次 $=9^{\mathrm{h}} 15^{\prime} 10 \%$ Pep$\sin$ 液體重 pro Kilo $1.0 \mathrm{ccm}$. 腹腔 內二注入後唯僅力 = Congo 陽性, 液流出ンタレドモ 斯カル量ニテ八分

泌ヨ巷起セシモノト認ムルヨ得ブ。

第 10 表 $9^{\text {h }} 0^{\prime}$ a.m. $10 \%$ Pepsin 體重 pro Kilo $1.0 \mathrm{ccm}$. 腹腔内注入䔈驗 實驗大 Nr. 25 尔褐白 (26/VW 1930 手術) 體重 14.500 䣶

\begin{tabular}{|c|c|c|c|c|c|c|c|c|c|c|c|}
\hline \multirow{2}{*}{ 時 } & \multicolumn{5}{|c|}{$\begin{array}{c}9^{\mathrm{h}} 0^{\prime} \text { 試驗食投與實驗 } \\
(5 / \mathrm{X} \quad 1930)\end{array}$} & \multicolumn{6}{|c|}{ 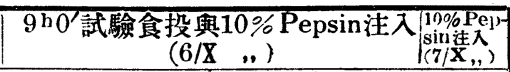 } \\
\hline & \begin{tabular}{|c|} 
胃液量 \\
ccm.
\end{tabular} & 總酸度 & 遊離雉䉡 & $\mid$ & Pepsin & $\mid \begin{array}{c}\text { 胃液量 } \\
\text { ccm. }\end{array}$ & 總酸度 & 遊離雉 & 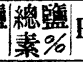 & Pepsin & $\begin{array}{c}\text { 胃液量 } \\
\text { ccm. }\end{array}$ \\
\hline $8^{\mathrm{h}} 0^{\prime}-9 \mathrm{~h} 0^{\prime}$ & $\begin{array}{r}0.57 \\
(\text { 粘液 }) \\
\end{array}$ & & $\begin{array}{c}\text { Congo } \\
(-)\end{array}$ & & & $\mid \begin{array}{r}0.65 \\
(\text { 粘液 }) \\
\end{array}$ & & $\begin{array}{c}\text { Congo } \\
(-)\end{array}$ & & & $\begin{array}{c}0.75 \\
(\text { 粘淮) } \\
\end{array}$ \\
\hline $9^{\mathrm{h}} 0^{\prime}$ & 2.92 & 135.5 & 123.0 & 0.58 & 960 & 4.52 & 139.8 & 129.5 & 50.56 & 960 & $\begin{array}{l}0.25 \\
(, .,)\end{array}$ \\
\hline $9^{\mathrm{h}} 45^{\prime}-10^{\mathrm{b}} 30^{\prime}$ & 0.99 & 110.5 & 99.8 & 30.55 & 1440 & 1.20 & 132.1 & 121.4 & .57 & 960 & $\begin{array}{l}0.10 \\
(,,)\end{array}$ \\
\hline $10^{h} 30^{\prime}-11^{h} 15^{\prime}$ & 0.95 & 102.3 & 91.2 & 0.56 & 1920 & 0.75 & 118.5 & 109.5 & 50.58 & 1440 & 0 \\
\hline $11^{\mathrm{h}} 15^{\prime}-0^{\mathrm{h}} 0^{\prime}$ & 1.66 & 105.3 & 90.4 & 40.57 & 1920 & 2.05 & 129.5 & 120.3 & 30.55 & 960 & 濩 \\
\hline
\end{tabular}

實驗例. 第 10 表。實驗犬 Nr. 26 今褐白. 䯤重 14.500 䣶試驗食 7 投與シ同時 $=10 \%$ Pepsin 液 $习$ 注入セル場合八單二試驗食 $\exists$ 投與シタル場合二比シ多少分泌ハ高マリ且ツ酸度モ稍了高值 ヨ示セドモPepsin力八左程高マラズ. 次二空腹時Pepsin 液 7 注入シタル場合、全ク胃液ノ分 䎵港起セラル、ヨ認メズ。

\section{第五章 酸度竝 $=$ Pepsin =就 テ}

胃液酸度ハ㱠ンド常二規則正シク胃液分泌量ト本行セリ．郎チ分泌速度ノ大ナルニ 從七テ酸度八亚?上昇入.反之分泌速度減少七八゙酸度モ亦從ツテ降下入然ルニPepsin 量二關シテハ之レト全ク反對ニシテ一般二分泌力ノ增加ハPepsin 量ノ減少チ示セリ. 以上八胃液分泌二關スル重要ナル法則卜見做サレ居ル所ノ所見ナレドモ立二興味アル 事實八即于胃粘液ガ以上ノ關係き說明スル上二極メテ意義アルノミナラズ少ホ場合二 估リテハ之レニ著明ナル動播き起サシムル點ナリトス. 元來消化液中, 無機物ハソ, 


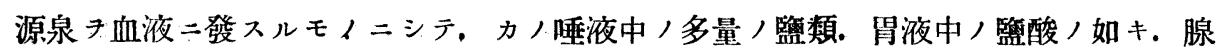
自己, 特殊, 機能二因ルニセヨ. 皆り, 材料ハ之レキ血液ナル大河ョリ得ルモノニ テ胃液 1 日ノ正常分泌量 $1 \frac{1}{2}-2$ Liter トセバ O. Cohnheim /認メシ如ク血声中，

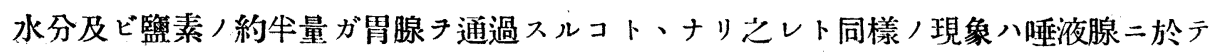
モ觀察セラレシ所ニシテ胃液分泌力ノ增加が胃液酸度,上昇キ來ス八喠液分泌力八增 加ガ無機監類含有量,上昇オ來スト同樣, 關係ニ在ル點ヨリ理解シ得ラルレドモ.

J. P. Pawlow ${ }^{(18)}$,Heidenhain ${ }^{(19)}$ 及ビ Ketscher $^{(20)}$ 等, 研究二ヨリ此, 胃液酸度, 動播

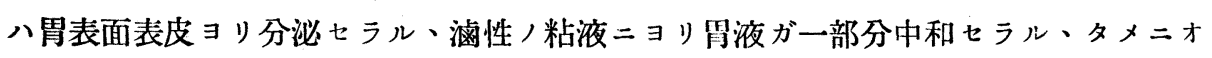
コルモノナルコトガ知ラレタリ。之レ今日二於テ諸學者/齊シク認ムル所ナリ．余， 實驗二於テモ試驗食き與へ分泌，開始七ラレテョリ最初，15 分間二採取セシ胃液八 沿次, 15 分間二採取七シ胃液ヨリソ八酸度八每常遥カ二低シ. 郎于監酸 Chlor \%量 八低っ反之監類 Chlor \%量八高シ。而シテ兩者ノ總 Chlor \%量二於テハ差異アルォ 認メズ. そレキ如何樣二說明スルカト云へバ胃液總 Chlor \%量八分泌ノ全經過中略? 一定ナリ。 之レニ關スル Rosemann，研究八實二有名ナルモノナレドモ恐ラク胃液 中，Chlor ガ血液ナル大町藏所ヨリ來ル關係上ソ，財源八比較的大二シテ Chlor， 胃內排泄八至ツテ自由ナリ，從ツテ胃液分泌速度ノ大ナル場合卜小ナル場合ト二於テ

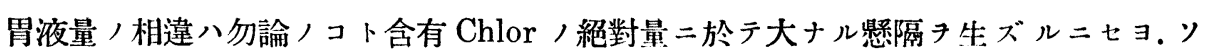
ノ含有\%量二就キテ考フル二生理的分泌狀態ニ在リテハ胃腺ハ常二一定, Chlor 量 含有スル胃液丹分泌スルモノニシテえレガ試驗食投與ニヨリテ最初分泌七ラル、際ニ 八胃內面ヨ覆へル粘液二必ズ接觸スルモノニシテ胃液ハ此ノ粘液ニョリテ一部分中和 七ラレ小胃內二胃管，插入七ラレアル場合ハえレキ通シテ粘液ト共二流出スルナリ。 依ツテ分泌ノ最初ニアリテハ胃內/粘液ニヨリ作用セラル、事最モ强シ. 然ル二分泌 ノ經過卜共二粘液八胃液卜共二胃管ニヨリ瘦孔外二流出シ今マデ盟内面テ覆へル粘液 八次第二減少スルニヨリ漸次分泌セラル、胃液八粘液, 中和テ受クルコト尠クナリソ ノ結果酸度八上昇ス而シテ一方胃液分泌速度が高マレバ胃粘液二作用サル、時間ガ短

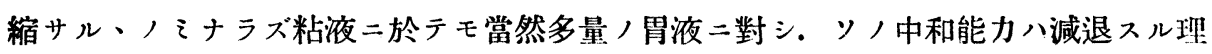
ニシテ. 要スルニ胃液酸度八分泌時二於ケル胃液卜粘液, 量的關係卜接觸時間，長短 トニヨリテ支配七ラル、モノナリ. 從ツテ假リ二分泌量大ナリトスルモ粘液量ガ之レ 二相當シテ大ナラバ決シテ酸度，上昇テ來サズ. 例へバ胃液分泌が試驗食投與後 2 時 間以上比較的著明二持續シタル場合第 1 時間目卜第 2 時間目トナ比較シソノ分泌量二 於テ前者が後者二優ルトモソノ酸度二於テ前者が後者二劣ル場合アルハ余，屢了實驗 
シタル所ナリ．えレ胃內ノ粘液ノ中和作用ニヨルモノニシテ殊二胃內ノ粘液最初胃 管ニヨリ排除シ置カズシテ直チニ試鰻食キ與へ胃液キ探取シタル場合ニ於テ然リト ス. 最初允分二胃內ノ粘液キ排除シタル後試驗食き投與シ胃管ニョリテ胃液キ探取シ タル場合八多ク分泌量ト酸度トハ相站行スルニ至ル。佾又試驗食き投與シ胃管き插入 セズ分泌サル、胃液キシテ小胃內二貯溜セシメ一定時間後一時二胃管ニョリ探取セル 場合卜 空腹時最初胃管キ插入シ小胃內/粘液ノ流出キ終リタル後試驗食キ投與シ分 泌サル、胃液き逐次分劃的二探取シ一定時間量き合シタル場合トォ比較スルニ多ク， 場合前者二於テ酸度, 低キチ實媛スルチ得タリ。以上小胃々液酸度ハ小胃內粘液, 作 用キ受ケ其ノ值キ減ズ。えレチ例示スレバ次ノ如シ。

第 11 表 胃管插入卜同時二試驗食

, 胃液量卜酸度卜, 關係习示ス。賽驗大 Nr. 18

令黃白. 體重 13.550 玍(13/XI 1929 手術)

\begin{tabular}{|c|c|c|c|c|c|}
\hline $\begin{array}{lr}\text { 時 } & \text { 日 } \\
14 / 1 \quad 1930\end{array}$ & \begin{tabular}{|c} 
液量 \\
ccm.
\end{tabular} & 總酸度 & 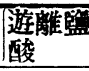 & 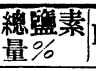 & Pepsin \\
\hline \multicolumn{6}{|c|}{$9 \mathrm{~h} 45^{\prime}$ 胃管插入同時二試驗食投與 } \\
\hline $\begin{array}{l}9^{\mathrm{h}} 45^{\prime}-10^{\mathrm{h}} 0^{\prime} \\
\text { a.m. }\end{array}$ & 0.55 & \multirow{4}{*}{89.3} & \multirow{4}{*}{79.7} & \multirow{4}{*}{0.562} & \multirow{4}{*}{1440} \\
\hline $10^{\mathrm{h}} 0^{\prime}-15^{\prime}$ & 1.68 & & & & \\
\hline $10 \mathrm{~h} 15^{\prime}-30^{\prime}$ & 0.85 & & & & \\
\hline $10_{\mathrm{h}} 30^{\prime}-45^{\prime}$ & 0.38 & & & & \\
\hline $10^{\mathrm{h}} 45^{\prime}-11^{\mathrm{h}} 0^{\prime}$ & 0.59 & \multirow{4}{*}{136.1} & \multirow{4}{*}{125.7} & \multirow{4}{*}{0.573} & \multirow{4}{*}{960} \\
\hline $11_{1} 0^{\prime}-15^{\prime}$ & 0.47 & & & & \\
\hline $11 \mathrm{~h} 15^{\prime}-30^{\prime}$ & 0.65 & & & & \\
\hline $11^{\mathrm{h}} 30^{\prime}-45^{\prime}$ & 0.43 & & & & \\
\hline
\end{tabular}

第 12 表 試驗食投舆卜胃管插入卜，時間的關係が胃 液酸度二及ボス影響ヨ示ス. 實驗大 Nr. 10 今白 黑. 顝重 17.260 硅 (11/V 1929 手術)

\begin{tabular}{|c|c|c|c|c|c|}
\hline 時 & $\begin{array}{l}\text { 胃液量 } \\
\text { ccm. }\end{array}$ & 總酸度 & 游離祭 & 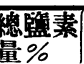 & Pepsin \\
\hline \multicolumn{6}{|c|}{ 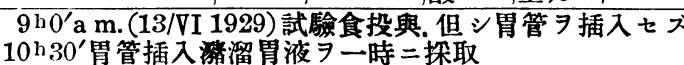 } \\
\hline $9 \mathrm{~h} 0^{\prime}-10^{\mathrm{h}} 30^{\prime}$ & 2.30 & \multirow[b]{2}{*}{132.4} & \multirow[b]{2}{*}{123.8} & \multirow[b]{2}{*}{0.57} & \multirow[b]{2}{*}{960} \\
\hline $10^{\mathrm{h}} 30^{\prime}-45^{\prime}$ & 8.40 & & & & \\
\hline \multicolumn{6}{|c|}{$8^{\mathrm{n}} 30^{\prime}$ a.m. (14/VI 1929) 胃管插入. 小胃內粘液，流出 } \\
\hline $8^{\mathrm{h}} 30^{\prime}-9 \mathrm{~h} 0^{\prime}$ & $\begin{array}{c}0.45 \\
\text { (粘液) }\end{array}$ & & Congo & & \\
\hline \multicolumn{6}{|c|}{$9^{\text {h }} 0^{\prime}$ a.m. 試驗食投興 } \\
\hline $9^{\mathrm{h}} 0^{\prime}-15^{\prime}$ & 1.40 & \multirow{7}{*}{141.3} & \multirow{7}{*}{133.5} & \multirow{7}{*}{0.58} & \multirow{7}{*}{1440} \\
\hline $9^{\mathrm{h}} 15^{\prime}-30^{\prime}$ & 2.11 & & & & \\
\hline $9^{\mathrm{b}} 30^{\prime}-45^{\prime}$ & 1.15 & & & & \\
\hline $9^{\mathrm{h}} 45^{\prime}-10^{\mathrm{h}} 0^{\prime}$ & 0.53 & & & & \\
\hline $10^{\mathrm{h}} 0^{\prime}-15^{\prime}$ & 0.62 & & & & \\
\hline $10^{\mathrm{h}} 15^{\prime}-30^{\prime}$ & 0.43 & & & & \\
\hline $10 \mathrm{~h} 30^{\prime}-45^{\prime}$ & 0.39 & & & & \\
\hline
\end{tabular}

實驗例。第 11 表實䮦犬 $\mathrm{Nr}$. 18 今撗白. 體重 13.550 斾 (13/XI 1929 手術). $9^{\mathrm{n}} 45^{\prime}$ a.m. 胃管插入 卜同時二試驗食习投與シソノ後 ，分泌胃液量卜酸度卜，關係习 見ルニ最初, 1 時間量入次, 1 時間量二比シ遙力二多量ナレド モ前者二八粘液站二粘液片, 多 量混在セルニ對シ後者ハ少シモ 粘液习含マズシテ胃液八全ク水 椂透明ナリ。酸度 7 見ル二前者 八後者ヨりモ低度ヨ示セり。郎 千此, 際前者が胃液量多キ二拘 ヘラズ酸度，低キ八粘液，混在 セルニ因ルナルぶシ。總䇛素量 於テ八大差ナクレドモPepsin 量二於テ八幾分前者, 後者二優 レ居ルヨ知ル. 之レモ亦後述ス ル如ク粘液分泌量二關係セルモ ノナラン。

實驗例。第 12 表。實驗大 Nr. 10 今白黑. 鳁重 17.260 㱠 $(11 / \mathrm{V}$ 1929 手衍). $9 \mathrm{~b} 0^{\prime}$ a.m. (13/VI 19 29）試驗食 $习$ 投與但シ胃管 $习$ 插 入シ置カプ. ソノ後10h30'マデ 自然落下スル胃菠 $2.30 \mathrm{ccm}$. 7

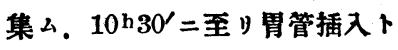
同時二流出ス儿洣溜胃波 


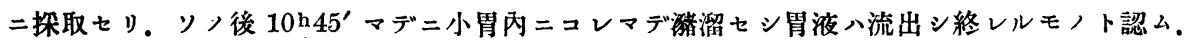
ソノ量 8.40ccm. ナリ. 次二同一犬二就キ翌日, 實驗成績 7 見ル

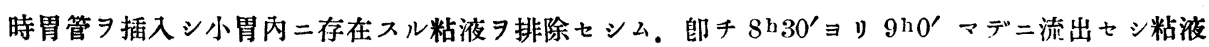
量 $0.45 \mathrm{ccm}$. ナリ. $9 \mathrm{~h} 0^{\prime}$ a.m. 試驗食 $习$ 投與シ $15^{\prime}$ 每二分劃的二探取セシ胃液量八表示セルが如

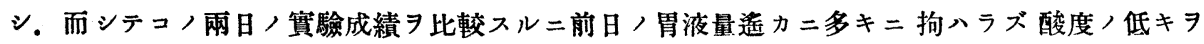
示七リ．之レ前日二於テへ胃液が長ク小胃內二停滞シ粘液, 作用 7 受ケタル篇卜後日二於テ、 試驗食 $习$ 投與スル前二豫入小胃內/粘液ヨ排除セシメ置キタルタメ試驗食投與後, 胃液が粘液 こそシカリシタメトニ因ルモノナラン. 總監素量二於テ大差ナクPepsin 量二於テハ後日，實驗 成績稍了高キヨ示セり.之レ八分泌胃液量/前日二比シ少ナカリシニ因ルナルベシ。

Pilocarpin ガ胃液分泌子催進セシムル八周知/事實ナレドモ.ソノ分泌量從ツテ酸 度二於テ Histamin /其レニ及バザルコト遠シ. Pilocarpinノ特徵トスル所八郎千胃 粘液ノ分泌テ高ムル點ニアリ. 而シテ此ノ際Pepsin酵素力ノ高マレルコト實二警クニ 堪へタリ.酸度八每常比較的低キキ實驗セリ。斯クノ如ク胃粘液ガ胃液酸度, 變化き起 サシムルコトハ極メテ明白トナレルガ玆二少Rosemann（胃液酸度，變化，原因トシ

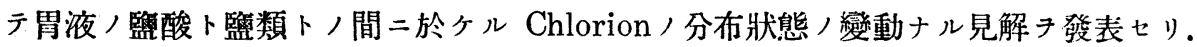

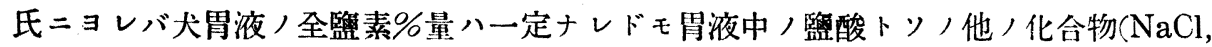

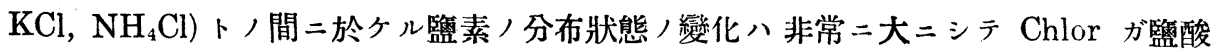
ノ形二於テ多量二存スレバ存スル丈監類トシテノChlor ハ少シト唱へ居り。事實二 於テソ/通リナレドモ之レニ關シテノ余，見解ハ知張り盟液卜粘液卜，量的關係二シ テ帠粘液八常二少量宛間斷ナク分泌七ラレソ, 量八略々一定セルモノナルガ故二ソ，

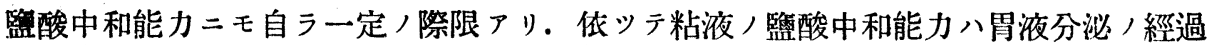
中略々一定セリト考フルコトキ得ベシ。然ルニ署液/分泌量八其, 變動頗ル大ニシテ 一試驗食投與後分劃的二採取スル二其ノ分泌，旺盛ナル時刻卜分泌ノ最初乃至八終期 二於テ微弱トナリシ時刻ト二於ケル監酸ノ絕對分泌量ニハ大ナル相違アリ。依ツテ分 泌力ノ大ナル場合程監酸ノ粘液ニヨリ中和サル、割合ハ少クシテ從ツテ監酸 Chlor\% 量ハ大ニシテ監類 Chlor \%量ハ小トナルワタナリ.反之分泌力ノ小ナル場合程監酸， 粘液ニョリ中和サル、割合ハ大トナリ從ツテ監酸 Chlor \%量ハ小トナリ覧類 Chlor \%量ハ大トナル。蓋シ胃液總 Chlor \%量！何レノ場合二モ殆ンド一定セルガ如シ. 且ツ胃液中ノ鹽酸モ分泌ノ一經過中略了一定/濃度二於テ生成七ラル、モノナラント 思惟ス。從ツテ監酸トシテ, Chlor \%量八略々一定ナル筈ナレドモ以上ノ理ニヨリ 監酸 Chlor \%量. 從ツテ酸度二影響テ來スモ，ト考へラル．而シテ前述セシ如ク胃 液分泌，最初師于試驗食投與後 15 分乃至 30 分二採取シタル胃液ハ小帠內キ輀へル多

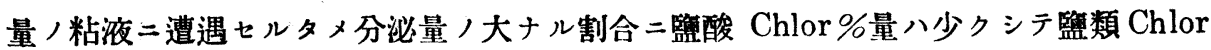


\%量ハ每常大ナルテ實驗セリ。少分泌ノ末期二於テハ胃液量八著明二減少スレドモ粘 液量ハ依然トシテ減少セザルガ故二必ズ監酸 Chlor \%量ハ大イ二減シ鹽類 Chlor\%量 八必ズ增加ス。

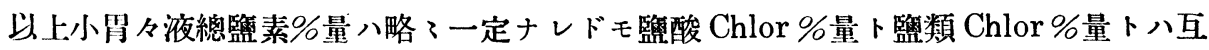
ヒ二反比例チナシテ增減ス。之レチ例示スレバ次ノ如シ。

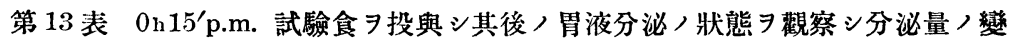
化比較的著シカラザル場合二於ケル各Chlor \%量 ヨ示ス。賽驗大 Nr. 19 令體重 11.840 纴（15/11 1930 手術）

\begin{tabular}{|c|c|c|c|c|c|}
\hline $\begin{array}{cc}\text { 時 } & \text { 日 } \\
23 / \text { m } & 1930\end{array}$ & $\begin{array}{c}\text { 霄 液 量 } \\
\text { ccm. }\end{array}$ & $\begin{array}{l}\text { 總 留 素 } \\
\text { \% }\end{array}$ & $\begin{array}{l}\text { 遊離監酸) } \\
\text { Chlor \% }\end{array}$ & $\begin{array}{l}\text { 結合鹽酸ノ } \\
\text { Chlor \% }\end{array}$ & $\begin{array}{l}\text { 鰡 類 } \\
\text { Chlor \% }\end{array}$ \\
\hline $\begin{array}{c}3 \mathrm{~h} 45^{\prime}-4^{\mathrm{h}} 0^{\prime} \\
\text { p.m. }\end{array}$ & 0.70 & \multirow{4}{*}{0.563} & \multirow{4}{*}{0.384} & \multirow{4}{*}{0.151} & \multirow{4}{*}{0.028} \\
\hline $4^{\mathrm{h}} \quad 0^{\prime}-15^{\prime}$ & 0.64 & & & & \\
\hline $4 \mathrm{~h} 15^{\prime}-30^{\prime}$ & 0.57 & & & & \\
\hline $4 \mathrm{~h} 30^{\prime}-45^{\prime}$ & 0.74 & & & & \\
\hline $4^{\mathrm{h}} 45^{\prime}-5_{\mathrm{h}} 0^{\prime}$ & 0.67 & \multirow{4}{*}{0.567} & \multirow{4}{*}{0.415} & \multirow{4}{*}{0.129} & \multirow{4}{*}{0.023} \\
\hline $5^{\mathrm{b}} \quad 0^{\prime}-15^{\prime}$ & 0.63 & & & & \\
\hline $5 \mathrm{~h} 15^{\prime}-30^{\prime}$ & 0.70 & & & & \\
\hline $5^{h} 30^{\prime}-45^{\prime}$ & 0.80 & & & & \\
\hline
\end{tabular}

實驗例。第 13 表。實驗大 Nr. 19 今體重 11.840 䏕(15/I 1930手術)。0h15'p.m.（23/m 1930) 試 驗食习投與シ其後, 胃液分泌, 狀態 7 觀察シ 分泌量, 變化, 比較的著シカラザル場合二於ケル

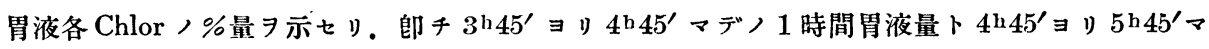
デノ 1 時間胃液量トヨ比較スルニ大差アルヨ認メズ. 唯僅カ二後者二於テ增量アルヨ認ムルノミ

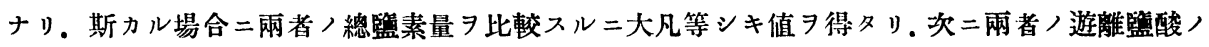

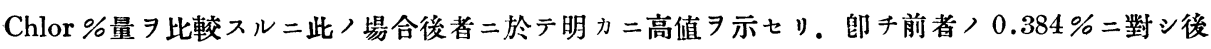
者八 $0.415 \%$ リ。次二結合監酸，Chlor \%量 ヨ比較スル二遊離監酸，場合卜八反對二前者二於

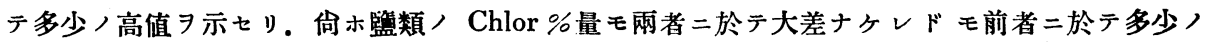
增加アルヨ見ル。以上胃液分泌量/變化少キ場合從ッテ酸度/變動少キ場合二於テモ遊離籃酸 ，減少八結合監酸站二監類 Chlor / 增加 7 實驗七り。之レ遊離監酸，減少八胃液中八有機成分站

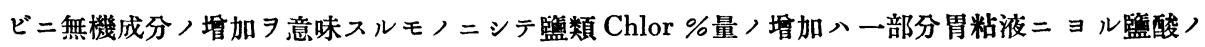
中和二由來スルモノト考へラル。以上ノ關係八次，實駼例 見レバ一層明暸トナル。

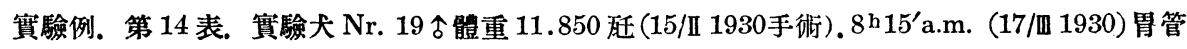
ヨ插入シ小胃內/粘液习排除シタル後。 $8^{\mathrm{h}} 45^{\prime}$ 試驗食 7 與へ胃液习探取ス。分泌量變化/著シキ

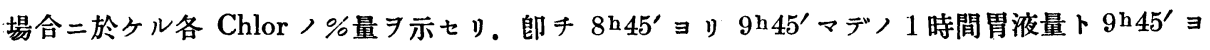
り) $10^{\mathrm{h}} 45^{\prime}$ マデ， 1 時間胃液量ト $\exists$ 此較スルニ大ナル差アリ。前者 $4.63 \mathrm{ccm}$. 二對シ後者 1.57

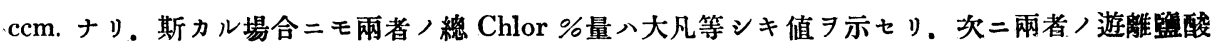

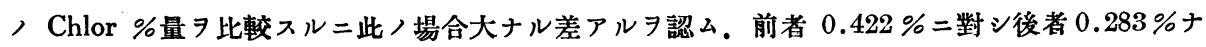

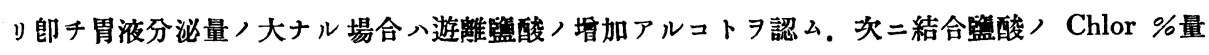

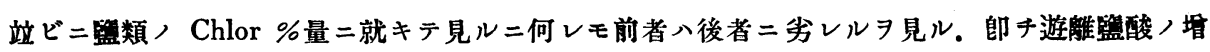

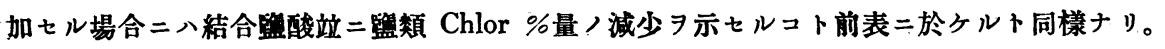


第 14 表 8h15'a.m. 胃管

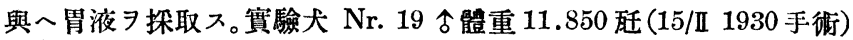
分泌量戀化ノ著シキ場合二於ヶル各 Chlor ノ\%量习示ス。

\begin{tabular}{|c|c|c|c|c|c|}
\hline 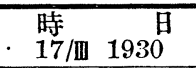 & $\begin{array}{c}\text { 畐 液 量 } \\
\text { ccm. }\end{array}$ & 總 Chlor\% & 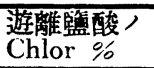 & $\begin{array}{l}\text { 結合監酸 } \\
\text { Chlor \% }\end{array}$ & 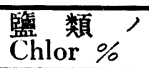 \\
\hline $\begin{array}{c}8 \mathrm{~h} 45^{\prime}-9 \mathrm{~h} 0^{\prime} \\
\text { a.m. }\end{array}$ & 1.66 & \multirow{4}{*}{0.561} & \multirow{4}{*}{0.422} & \multirow{4}{*}{0.104} & \multirow{4}{*}{0.035} \\
\hline $9 \mathrm{~h} 0^{\prime}-15^{\prime}$ & 1.68 & & & & \\
\hline $9 \mathrm{~h} 15^{\prime}-30^{\prime}$ & $0 . \overline{73}$ & & & & \\
\hline $9^{\mathrm{h}} 30^{\prime}-45^{\prime}$ & 0.56 & & & & \\
\hline $9 \mathrm{~h} 45^{\prime}-10^{\mathrm{h}} 0^{\prime}$ & 0.51 & \multirow{4}{*}{0.570} & \multirow{4}{*}{0.283} & \multirow{4}{*}{0.212} & \multirow{4}{*}{0.075} \\
\hline $10^{\mathrm{h}} 0^{\prime}-15^{\prime}$ & 0.36 & & & & \\
\hline $10^{\mathrm{h}} 15^{\prime}-30^{\prime}$ & 0.38 & & & & \\
\hline $10^{\mathrm{h}} 30^{\prime}-45^{\prime}$ & 0.32 & & & & \\
\hline
\end{tabular}

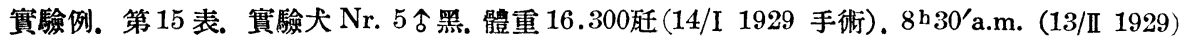
胃管插入卜同時二試驗食 7 投與シ分泌サル、胃液卜共二流出スル小胃內粘液 $モ モ$ 探取セル場合 ニ於ヶル胃液各 Chlor \%量, 變化ヨ示セリ. 胃液量ニツキテ此較スル $=30$ 分間量二於テ最初,

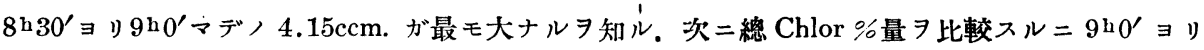

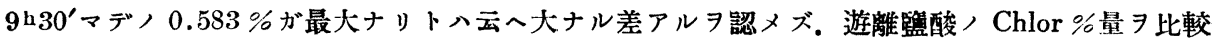

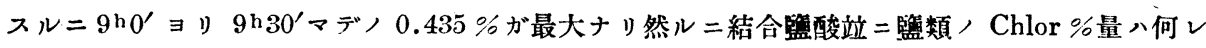
モ最小值ヨ示セリ. $8^{\mathrm{h}} 30^{\prime} ヨ リ 9^{\mathrm{b}} 0^{\prime}$ マデノ間八分泌力最大ナルニ拘ハラズ遊陮監酸, Chlor \%

第 15 表 8 h $30^{\prime}$ a.m. 胃管插入ト同時二試驗会 7 投與シ分泌サル、胃液卜共二流 出スル小胃內粘液 $7 モ$ 探取セル場合. 實駼犬 Nr. 5 令黑. 體重 16.3 00 歼 (14/I 1929 手術)

\begin{tabular}{|c|c|c|c|c|c|}
\hline $\begin{array}{lr}\text { 時 } & \text { 日 } \\
13 / \text { II } & 1929\end{array}$ & $\begin{array}{c}\text { 苗 液 量 } \\
\text { ccm. }\end{array}$ & 總 Chlor \% & $\begin{array}{l}\text { 遊離監酸， } \\
\text { Chlor \% }\end{array}$ & $\begin{array}{l}\text { 結合監酸ノ } \\
\text { Chlor \% }\end{array}$ & 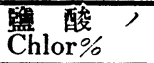 \\
\hline $\begin{array}{c}8^{\mathrm{h}} 30^{\prime}-9^{\mathrm{h}} 0^{\prime} \\
\text { a.m. }\end{array}$ & 4.15 & 0.564 & 0.376 & 0.143 & 0.045 \\
\hline $9 \mathrm{~h} \quad 0^{\prime}-30^{\prime}$ & 3.80 & 0.583 & 0.435 & 0.119 & 0.029 \\
\hline $9 \mathrm{~h} 30^{\prime}-10^{\mathrm{h}} 0^{\prime}$ & 2.03 & 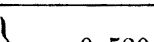 & & & \\
\hline $10 \mathrm{~h} 0^{\prime}--30^{\prime}$ & 2.45 & 0.580 & 0.403 & 0.136 & 0.041 \\
\hline $10^{\mathrm{h}} 30^{\prime}-11^{\mathrm{h}} 0^{\prime}$ & 0.86 & \multirow{4}{*}{0.572} & \multirow{4}{*}{0.294} & \multirow{4}{*}{0.210} & \multirow{4}{*}{0.068} \\
\hline $11^{\text {h }} 0^{\prime}-30^{\prime}$ & 0.75 & & & & \\
\hline $11^{\mathrm{h}} 30^{\prime}-0^{\mathrm{h}} 0^{\prime}$ & 0.58 & & & & \\
\hline $0^{\mathrm{h}} 0^{\prime}-30^{\prime}$ & 1.03 & & & & \\
\hline
\end{tabular}

量比較的低值 7 示シ四者中第三位 7 占ムルハ恐ラク最初小胃內 $\ni$ 覆ヘル粘液ノタメ二中和セラ

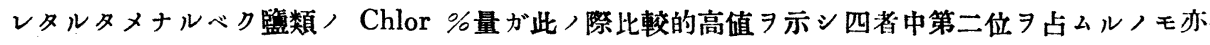
之レニョリテ芜明シ得ラル、モノナラント思惟ス. $10^{\mathrm{h}} 30^{\prime} ヨ リ 0^{\mathrm{h}} 30^{\prime}$ マデノ間八分泌モ至ッテ微

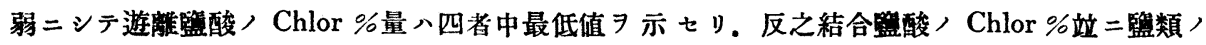
Chlor \%量八四者中最高值ヨ示七リ.之レ分泌ノ微弱トナリシ際殊二分泌八末期二於テ八明力

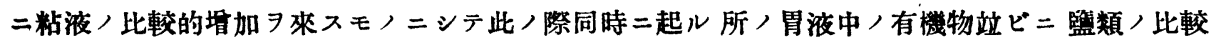

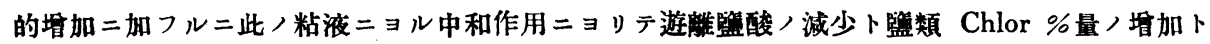
ヨ招來スルモノナラン。

次二尙ホーツ胃液分䎵量竝ビニ酸度, 變動テ起サシムル可能性トシテハ郎チ生體 


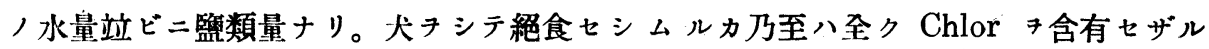

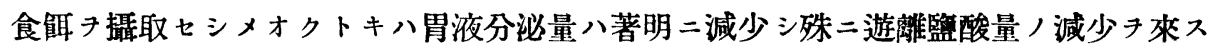
八明カニシテ此ノ際卜雖ドモ總 Chlor \%量二八變動無キガ如シ. 以上ノ條件ノモトニ 更二生體ヨリ多量，Chlor ガ絶エズ奪ヒ去ラル・如キ場合例へバ Frémont， ,estomac sequestré” 二於テハ特二著明ニシテ Pawlow, ,Kleiner Magen” ニ於テ モ常二Chlor ノ消失アルガ故二無手術ノ犬二比シ以上ノ現象ハ一層速カ二出現スル モノナルコト想像二難カラズ。

既述胃粘液ガ胃液分泌ノ經過二於テ常二略:一定量宛產生セラレソノ動搖少キガ如 ^Pepsin 﨎生ニ在りテモ亦りノ絕對量二於テ變動少キモノト思惟ス余)試驗食(米 饭 250. 馬肉 150. 味噌 15. 水 300) キ與へテ觀察セシ所ニヨレバ分泌ノ初メ二於テ Pepsin 力最モ强っ分泌/旺盛トナル二從七減弱シ分泌ノ再ビ減退スルト共二酵素力 八上昇ス。之レ上述セル胃液中ノ籃類\%量/變動卜モ全ク相一致七リ。且ツ Pepsin 產生ハ一般二胃粘液產生卜密接, 關係アルモ, ト考へラル. 即于胃粘液分泌, 增加 ガ Pepsin力ノ上昇き來ス八事實ニシテPilocarpin注射ノ場合二容易ニえレォ觀察入 ルコトキ得。茲ニーツ興味アル事實ハ郎チ余ノ試驗食二於テハ大體上述七ル如ク常二 Pepsin 力ト胃液分泌量ト八互七二逆ノ結果タ得レドモ特二胃液分泌 强ク元進セシ ムル食慨. 例人バ馬肉ノ゙キ而モ大量與へタル如キ場合二八分泌ノ初メ二於ケル胃液 八Pepsin/最モ多量キ含有シ. 分泌〉最モ旺盛トナル時ハPepsin力八減退シ次二 分泌ハ末期二近ジキ分泌量，著シク減少七ルニモ拘ハラズ Pepsin 力八依然トシテ上 昇七ズ. 分泌ノ最モ旺盛ナル場合ョリモPepsin 力粪カ二劣レル場合アリ。之レ郎于 分泌ノ初期二於テ極メテ多量, Pepsin ガ分泌七ラレタル䉆ニシテ余ノ見解ニョレバ Pepsin 產生能力ニハ一定, 際限アルモノニシテ一時二多量, 胃液分泌アル場合二八 胃粘膜內二貯蓄七ラレタル Pepsin ガ一時二胃液ト共二分泌セラレ最早胃粘膜內， Pepsin 八減少シ後ヨリ漱次二作ラル、Pepsin 量ニハ際限アルノミナラズPepsin生 成能力ニモ減退き來ス結果ナラント考へラル。余八胃粘膜乾燥粉末內，Pepsin 量 測定セシニ颇ル顯著ナルタ認メタリ. 余八無手術ニシテ全ク健康ナル中等大. 體重 15

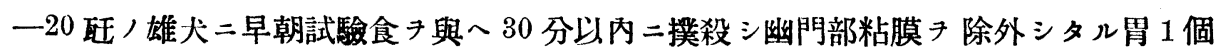

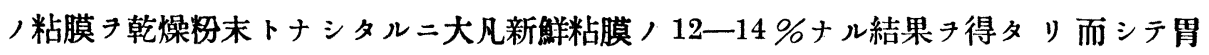
粘膜乾燥粉末 $(12 \%) ， 1.0 \%$ 学剂ニツキ Fuld-Laevison，Edestin 法二依リソノ中， Pepsin 量尹測定セシニ Pepsin 單位 512-1024 ル值キ得タリ. えレチPepsinMerckノ $1.0 \%$ 溶液二就キソ，Pepsin 力ョ同法ニョリテ測定セシ結果ハPepsin 單 
位 64-128+リ. 依ツテ胃粘膜乾燥粉末八Pepsin-Merck ヨリモ传カ二Pepsin力， 强大ナルチ知ル。斯ノ如ク胃粘膜內二八航述 Chlor /他二多量, Pepsin 存在ス. 而 シテ胃液分泌，開始卜共二Pepsin 八胃液トナリテ排泄セラルレドモ一時二大量，胃 液ガ分泌七ラル、場合二八此ノ貯藏 Pepsin 八悉ク分泌七ラル. 殊二 Histamin ノ大 量テ一時ニ注入スルカ又八餘リニ大量ナラザルモ引續キ幾回トナク注入スルトキハ胃 液中, Pepsin 力八谷了減退久。同樣ノ事實八 Pilocarpin ヨ引續キ注入シテモ亦明 暸二認メラル、モノナリ。其ノ他第 1 回ノ試驗食キ與ヘソノ後ノ分泌狀態キ觀察シソ ノ最モ旺盛ナル時期キ經過シ分泌ノ比較的二微弱トナリシモ未ダ終リキ告グルニ至ラ ザル頃郎チ多ク，場合第 1 回/試驗食投與後 2 時間以内二第 2 回/試驗食き投與シ䒚 引續キ經過き觀察スルニ前者，Pepsin 力八後者ノ其レニ比シ常二蝀カニ大ナルキ知 レリ。 以之觀是胃キシテ常二同程度二機能チ營マシメPepsin/產生チ本等ナラシム ルニ八食锃キ與フルニ一定ノ時間的間隔キ必要卜認ム。

第 16 表 馬肉 450g. 宛 2 包投與セル場 合, 胃液分泌狀意, 變化 7 示ス. 實驗犬 Nr. 3 菜占體重 18.800 䣶 (22/X1928 手術)

\begin{tabular}{|c|c|c|c|c|}
\hline $\begin{array}{cc}\text { 時 } & \text { 日 } \\
23 / \text { XII } & 1928 \\
\end{array}$ & $\left|\begin{array}{c}\text { 胃液量 } \\
\text { cc.m. }\end{array}\right|$ & \multirow[t]{2}{*}{ 總酸度 } & 酸 & $\overline{\text { Pepsin }}$ \\
\hline $\begin{array}{c}8 \mathrm{~h} 0^{\prime}-30^{\prime} \\
\text { a.m. }\end{array}$ & $\left|\begin{array}{c}0.35 \\
(\text { 粘液 })\end{array}\right|$ & & $\left|\begin{array}{c}\text { Congo } \\
(-)\end{array}\right|$ & \\
\hline $8^{\mathrm{h}} 30^{\prime}-45^{\prime}$ & 0 & & & \\
\hline \multicolumn{5}{|c|}{$8^{\mathrm{h}} 45^{\prime}$ 馬肉 $450 \mathrm{~g}$. 投興 } \\
\hline $8 \mathrm{~h} 45^{\prime}-9 \mathrm{~h} 0^{\prime}$ & 1.58 & \multirow{2}{*}{136.4} & \multirow{2}{*}{124.9} & \multirow{2}{*}{1024} \\
\hline 9 h $0^{\prime}-15^{\prime}$ & 4.36 & & & \\
\hline $9^{\mathrm{h}} 15^{\prime}-30^{\prime}$ & 3.75 & \multirow{2}{*}{142.7} & \multirow{2}{*}{134.3} & \multirow{2}{*}{512} \\
\hline $9 \mathrm{~h} 30^{\prime}-45^{\prime}$ & 3.25 & & & \\
\hline $9 \mathrm{~b} 45^{\prime}-10^{\mathrm{h} 0^{\prime}}$ & 1.66 & \multirow{2}{*}{128.8} & \multirow{2}{*}{121.4} & \multirow{2}{*}{768} \\
\hline $10^{\mathrm{h}} 0^{\prime}-15^{\prime}$ & 0.95 & & & \\
\hline \multicolumn{5}{|c|}{$10^{\mathrm{h}} 15^{\prime}$ 馬肉 $450 \mathrm{~g}$ 投與 } \\
\hline $10^{\mathrm{h}} 15^{\prime}-30^{\prime}$ & 0.84 & \multirow{2}{*}{133.7} & \multirow{2}{*}{126.6} & \multirow{2}{*}{512} \\
\hline $10^{\mathrm{b}} 30^{\prime}-45^{\prime}$ & 3.85 & & & \\
\hline $10^{\mathrm{b}} 45^{\prime}-11^{\mathrm{h}} 0^{\prime}$ & 2.24 & \multirow{2}{*}{129.6} & \multirow{2}{*}{123.2} & \multirow{2}{*}{256} \\
\hline $11^{\mathrm{h}} 0^{\prime}-15^{\prime}$ & 2.30 & & & \\
\hline $11^{\mathrm{h}} 15^{\prime}-30^{\prime}$ & 1.06 & \multirow{2}{*}{124.5} & \multirow{2}{*}{116.8} & \multirow{2}{*}{384} \\
\hline $11^{\mathrm{h}} 30^{\prime}-45^{\prime}$ & 0.88 & & & \\
\hline
\end{tabular}

賽驗例. 第 16 表. 賽驗大Nr. 3 茶古體 重 18.800 哌 (22/X 1928 手術) 馬肉 $450 \mathrm{~g}$. 宛 2 回投與七ル場合，胃液分泌狀態，變 化 $ᄏ$ 示七り。即チ $8^{\mathrm{h}} 0^{\prime}$ a.m. (23/XII 1928) 胃管习插入シ小胃內/粘液, 排泄セラレ タル後 $8 \mathrm{~h} 45^{\prime}$ 騂肉 $450 \mathrm{~g}$. ᄏ投與セり。ソ ，後 $10^{\mathrm{h}} 15^{\prime}$ マデ 1 時間 30 分，間 15 分 每二胃液 $习$ 探取 $シ 30$ 分間每二酸度站二 Pepsin 7 测定セシ結果八最初，30分間 二於テ Pepsin 力最モ大ナりキ而シテ酸 度二於テ、次， 30 分間二探取七シ胃液 ヨリ多少低シ. $9 \mathrm{~h} 15^{\prime} ヨ$ ヨ $9 \mathrm{~h} 45^{\prime}$ マデ， 間八分泌量最モ大ニシテ從ッテ酸度モ最 モ高ケレドモPepsin 力八反之最モ低 シ. 次 30 分間郎 $9^{\mathrm{h}} 45^{\prime} \exists$ リ $10^{\mathrm{b}} 15^{\prime}$ マデノ間八分泌量，著明ナル減少 7 來セ リ、從ッテ酸度モ亦最モ低シ。反之Pepsin 力八多少上昇 $コ$ 示七ドモ最初, 30 分間 二於ケルPepsin 力二及バズ、次 $=10^{\mathrm{h}} 15^{\prime}$

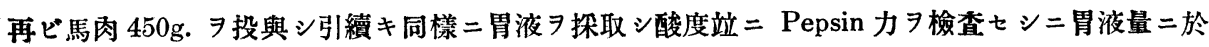
テモ佾酸度站ビニPepsin カニ於テモ前實驗成績ニ比シ明カニ低值 減少 7 來セルコト最モ著明ナリ. 以上ノ成績八胃液分泌 7 强ク艺進セシムルニ馬肉 7 比較的多量 二且ツ短キ時間內 $=2$ 度投與シタルガ爲メナリ。

實驗例. 第 17 表. 實驗犬 Nr. 4 黑白古體重 20.300歼(20/X 1928 手術). 0.1\% Pilocarpin. hy- 
第 17 表 $0.1 \%$ Pilocarpin. hydrochlor. 习腎筋内二注入七儿場合，胃液分泌 狀態 $゙$ 示ス. 實驗大 Nr. 4 黑白令 $(20 / \mathrm{X} 1928$ 手術) 體重 20.300 玍

\begin{tabular}{|c|c|c|c|c|}
\hline $\begin{array}{ll}\text { 時 } & \text { 日 } \\
25 / \text { XII } & 1928\end{array}$ & $\left|\begin{array}{c}\text { 栗液量 } \\
\text { ccm. }\end{array}\right|$ & 總酸度 & 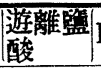 & Pepsin \\
\hline $\begin{array}{c}8^{8} 0^{\prime}-30^{\prime} \\
\text { a.m. }\end{array}$ & $\begin{array}{c}0.35 \\
(\text { 粘液 })\end{array}$ & & & \\
\hline $8 \mathrm{n} 30^{\prime}-45^{\prime}$ & 0 & & & \\
\hline \multicolumn{5}{|c|}{$8 \mathrm{~S} 45^{\prime}$ 試驗食投與. 同時 $=$ Pilocarpin2.0cc 注入 } \\
\hline $8 \mathrm{~h} 45^{\prime}-9 \mathrm{~h} 0^{\prime}$ & 1.46 & 131.6 & 120.3 & 2880 \\
\hline $9 \mathrm{~h} \sigma^{\prime}-15^{\prime}$ & 4.53 & 145.3 & 137.8 & 1920 \\
\hline $9^{\mathrm{h}} 15^{\prime}-30^{\prime}$ & 4.78 & 147.2 & 139.7 & 1920 \\
\hline $9^{\mathrm{h}} 30^{\prime}-45^{\prime}$ & 3.54 & 144.6 & 138.4 & 3840 \\
\hline \multicolumn{5}{|c|}{$9^{\mathrm{h}} 45^{\prime}$ Pilocarpin 2.0cc. 注入 } \\
\hline $9 \mathrm{~h}_{4} 5^{\prime}-10^{\mathrm{h}} 0^{\prime}$ & 3.28 & 140.7 & 133.5 & 1920 \\
\hline $10^{\mathrm{h}} 0^{\prime} \cdot-15^{\prime}$ & 4.13 & 141.2 & 134.8 & 960 \\
\hline $10^{\mathrm{h}} 15^{\prime}-30^{\prime}$ & 3.95 & \multirow{2}{*}{134.8} & \multirow{2}{*}{127.6} & \multirow{2}{*}{2880} \\
\hline $10^{\mathrm{h}} 30^{\prime}-45^{\prime}$ & 2.65 & & & \\
\hline \multicolumn{5}{|c|}{$10^{1} 45^{\prime}$ Pilocarpin 2.0cc. 注入 } \\
\hline $10^{\mathrm{h}} 45^{\prime}-11^{\mathrm{h}} 0^{\prime}$ & 1.27 & 123.7 & 111.2 & 960 \\
\hline $11^{\mathrm{h}} 0^{\prime}--15^{\prime}$ & $0 . \overline{95}$ & 118.6 & 107.3 & 1440 \\
\hline $11115^{\prime}-30^{\prime}$ & 1.08 & \multirow{2}{*}{108.3} & \multirow{2}{*}{96.9} & \multirow{2}{*}{1920} \\
\hline $11^{\mathrm{h}} 30^{\prime}-45^{\prime}$ & 0.53 & & & \\
\hline
\end{tabular}

第 18 表 $0.1 \%$ Histamin $\ni$ 腎筋內二注 入七ル場合，胃液分泌狀態习示ス。 賽驗大 Nr. 5 古黑. 體重 16.500 质壬 (14/I 1929 手術)

\begin{tabular}{|c|c|c|c|c|}
\hline 時 $25 / \mathbb{W}^{\prime} 1929$ 日 & $\left|\begin{array}{|c|c|}\text { 液量 } \\
\text { ccm. }\end{array}\right|$ & 總酸度 & 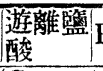 & $\overline{P e p s i n}$ \\
\hline $\begin{array}{c}8^{\mathrm{h}} 0^{\prime}-30^{\prime} \\
\text { a.m. }\end{array}$ & $\begin{array}{l}0.2 \\
\text { (粘液) }\end{array}$ & & $\left|\begin{array}{c}\text { Congo } \\
(-)\end{array}\right|$ & \\
\hline $8^{\mathrm{n}} 30^{\prime}-45^{\prime}$ & 0 & & & \\
\hline \multicolumn{5}{|c|}{$\begin{array}{l}8^{\mathrm{h}} 45^{\prime} \text { Histamin } 2.0 \mathrm{ccm} \text {. 注入 } \\
8^{\mathrm{h}} 52^{\prime} \text { 分泌開始サル }\end{array}$} \\
\hline $8^{\mathrm{h}} 45^{\prime}-9^{\mathrm{b}} 0^{\prime}$ & 2.15 & 139.5 & 127.5 & 1024 \\
\hline $9^{1} \quad 0^{\prime}-15^{\prime}$ & 7.43 & 151.3 & 147.3 & 512 \\
\hline $9^{n} 15^{\prime}-30^{\prime}$ & 5.25 & 150.2 & 147.2 & 512 \\
\hline $9^{\mathrm{b}} 30^{\prime}-45^{\prime}$ & 3.51 & 100. & & \\
\hline \multicolumn{5}{|c|}{$9^{\mathrm{h}} 45^{\prime}$ Histamin 2.0cc.m 注入 } \\
\hline $9^{\mathrm{h}} 45^{\prime}-10 \mathrm{~h} 0^{\prime}$ & 5.98 & 149.8 & 145.9 & 384 \\
\hline $10^{\mathrm{h}} 0^{\prime}-15^{\prime}$ & 7.05 & 153.2 & 149.6 & 256 \\
\hline $10^{\mathrm{h}} 15^{\prime}-30^{\prime}$ & 6.38 & 149. & 145.3 & 128 \\
\hline $10^{1} 30^{\prime}-45^{\prime}$ & 4.47 & & & \\
\hline \multicolumn{5}{|c|}{$10145^{\prime}$ Histamin $2.0 \mathrm{ccm}$. 注入 } \\
\hline $10^{\mathrm{h}} 4 \mathrm{u}^{\prime}-11^{\mathrm{h}} 0^{\prime}$ & 5.24 & 147.3 & 3143.8 & 128 \\
\hline $11^{\mathrm{h}} 0^{\prime}-15^{\prime}$ & 6.64 & 149.9 & 144.3 & 128 \\
\hline $11^{\mathrm{h}} 15^{\prime}-30^{\prime}$ & 4.13 & 141.9 & 136.5 & 96 \\
\hline $11^{\mathrm{h}} 30^{\prime}-45^{\prime}$ & 2.88 & & & \\
\hline
\end{tabular}

drochlor 7 篮筋內二注入セル場合，胃液

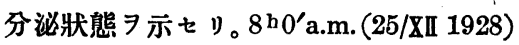
胃管习插入シ小胃內/ 粘液 7 排泟セシ ム. $8^{\mathrm{b}} 45^{\prime}$ 試驗食 7 投與 シ同時 $=$ Pilocarpin $(0.1 \%) 2.0 \mathrm{ccm}$. 尹腎筋内二注入七 リ. ソノ後 1 時間每 $=0.1 \%$ Pilocarpin $\Rightarrow 2.0 \mathrm{ccm}$. 宛 2 回同樣二注入ン胃液量 酸度站ビニPepsin 量ニッキテ檢查スル 二第 1 间, Pilocarpin 注入後 1 時間, 胃 液量酸度站 $=$ Pepsin 量最モ高值 $习$ 示七 リ. 而シテ第 3 回，Pilocarpin 注入後 1 時間, 胃液量酸度站二Pepsin 量入最モ 低值习示七り：コノ表二於テ最モ特異卜 スベキハPepsin 量ノ頗ル大ナル點ナリ トス. 佾又第 1 回，Pilocarpin 注入後， 胃液量站ビ二酸度,大ナル八同時二試驗 食习投與シタルが䉆ニシテ. Pilocarpin ノミヨ注入シタル際二八通例力、ル大量 ，胃液分泌アルヨ見ズ．從ツテ酸度モ通 常比較的低シ. 余が此，賽驗二於テ試驗 食习投與ンタルハ一時二多量, 胃液习排 泄セシメント努メタレバナリ。

實驗例. 第 18 表. 實驗大. Nr. 5 占黑. 體重 16.500 的（14/I 1929 手術） $0.1 \%$ Histamin 7 臂筋內二注入七ル場合, 胃

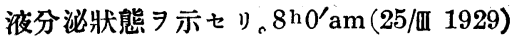
胃管 $习$ 插入シ小胃內二存在セル粘液ヨ排 泄セシム $8 \mathrm{~h} 45^{\prime}$ マデノ流出粘液量 $0.2 \mathrm{ccm}$. ニシテ此，場合比較的小量ナリ。 $8^{\mathrm{h} 45^{\prime}}$ $0.1 \%$ Histamin $2.0 \mathrm{ccm}$. ᄏ腎筋内二注入 セリ. 7 分後 $8 \mathrm{~b} 52^{\prime}$ 分泌開始セラレタリ。 遊離監酸习含么液, 流出 $习$ 以テ分泌, 開 始セラレタル時トナセリ．余ノ經驗 $=ョ$ レバ每常15分以內 $=$ 必ブ分泌ノ起ルント ヨ認メタリ。而シテ大抵ノ場合殆ンド規 則正シク 6 分乃至 8 分ニシテ分泌アリ。 $9 \mathrm{~h} 45^{\prime}$ 第 2 回，Histamin 注入 $\exists$ 行 $ヒ 10^{\mathrm{h}}$ $45^{\prime}$ 第 3 回/注入 $ヨ$ ナり。コ３回／注 入後, 胃液量酸度站 $ヒ ゙=P e p s i n$ 量 $尹$ 比 較スルニ胃液量二於テハ第 2 回，Histamin 注入後，1時間量最モ大ナルヨ知ル。向又何レノ場 
合二モHistamin 注入後 15 分ョリ30 分ノ間が分泌最モ旺盛ナルヨ見ル. Histamin ノコノ程度 ノ注入二於テハ分泌ノ著明ナルハ 1 時間以內ニシテ 1 時間後ハ分泌、極メテ微弱トナル. 次二 酸度二就キテ見ル二分泌力ノ大ナル場合八酸度モ之レニ從ッテ高值ヨ示セリ. Histamin，特徵 トスル所ハ酸分泌 ヨ高ムルニ在リ。コノ表二於テモ胃液量站ビ二酸度ノ大ナル Histamin 注入後モ倘分泌量及ビ酸度, 此較的高キヨ見ル. 次 $=$ Pepsin 量二就キテ見ル $=$ His-

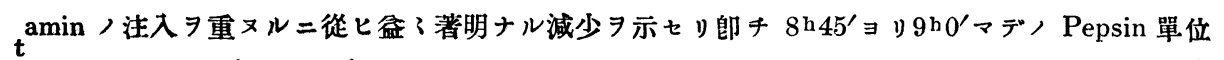
$1024 \exists リ 11^{\mathrm{h}} 15^{\prime} \exists y 45^{\prime}$ マデ，Pepsin 單位 96 二マデ隇少セリ。

丛上 3 表二示セル實驗八何レモ胃腺二對シ稍了過强ノ刺戟キ與へタルモノト思惟ス

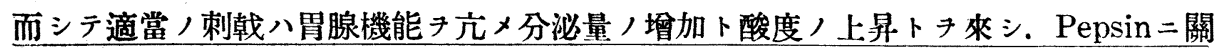
シテ八酸度ト一般二反對/態度キ示スモ少ソ八絕對量二於テ知張り增量キ示ス場合多

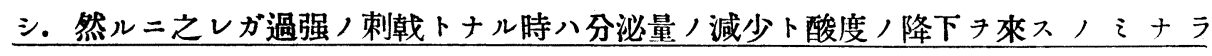
ㅈ․ Pepsin 二於テモソ/絕對量二於テ明カ二減少チ來シ. 胃腺機能，減退子起スモ ノナラン。

\section{第六章 總括及ビ結論}

以上キ總括結論スレバ次ノ如シ。

1) Pawlow 小胃手術後 3 週間以內ニアリテハー般二分泌ノ著明ナル 認 $\times$ 空腹時 多量, 胃液分泌アリ且ツ試驗食投與後, 分泌モ日ニヨリテ動播甚シク又 1 日/分䎵經 過中二モ週期的二增減アリ。

2) Pawlow 小胃手術後3 週間經過後ニアリテハ空腹時ニ於ケル著明ナル胃液分泌 八認メ難キニ至リ・且ツ試驗食投與後, 分泌モ每常略々一定シ大ナル動搖キ示サジル 二至ル。

3) 試驗食投與後分泌，開始サル、迄二一定，時間キ要ス. 少余／試驗食二於テハ 分泌ノ最大ナル時刻ハ 1 時間以內ナルォ通例トス。

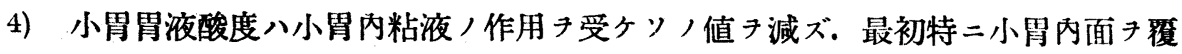
ヘル粘液キ排除シ置カズシテ試驗食タ投與シ胃液タ探取スル時ハ酸度ノ最高値タ示ス 時間ハ分泌量/最高き示ス時間ヨリモ明暸二遲延ス。總酸度ハ小胃純粹胃液ニアリテ

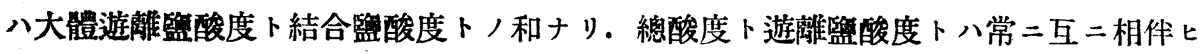
テ增減ス。小胃純粹胃液ニアリテ八兩者ノ差八特ニ小ナレドモ分泌ノ極初期又八末期 二於テ分泌，減少き來シタル場合二八兩者，差ハ大トナル。之レ結合監酸/增加來 スニヨルモノナリ。

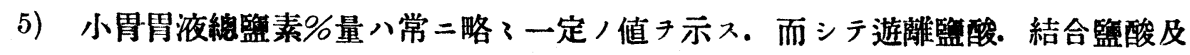




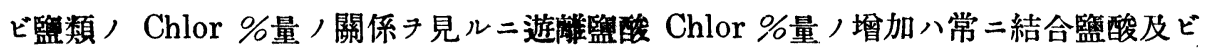

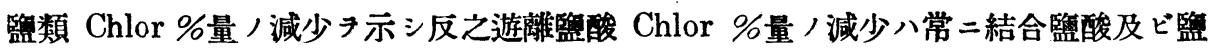
類 Chlor \%量ノ增加キ示セリ。遊離監酸 Chlor \%量八分泌量ト正比例チナシ・結合 㼂酸及ビ監類 Chlor \%量八分泌量ト反比例チナシテ增減スレドモ胃粘液モ亦後者卜 同樣分泌量卜反比例ナナス關係上監類 Chlor \%量，變動ハソレ自身ノ分泌ニヨル以外 二胃粘液, 有スル Alkali 二ヨリ監酸, 中和サル、程度, 大小ニョリテ來ルモノニシ テ. 胃液分泌/各期二於テ分泌量ノ變動頗ル大ナルチ以テ. 粘液ニヨリ監酸, 中和サ ル、程度ニ大ナル䜿隔アリ從ッテ分泌量／極メテ小ナル場合八監酸ノ大部分八粘液二

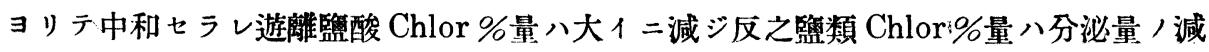
少ニ伴ヒ著明チル增加き來ス。

6) 試驗食き投與後一定時間キ經過シ胃管き插入シ胃液タ採取シタル場合八試驗食

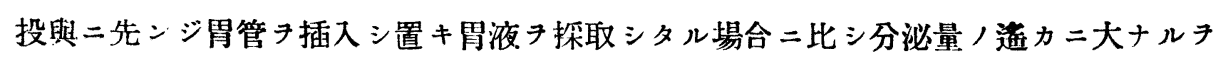
認么。

7）一定試驗食投與ノモト二連日胃液採取キ續ケタル後. 1 日胃液探取ヨ休ミタル トキハ其ノ柆日ノ探取量二明暸ナル增加アルコトフ確カメタリ．且ッPepsin 量二於 テモ增加テ來スモノト認ム。

8)。他犬ョリ得タル純粹中和胃液腹腔内二注入スルトキ八胃液分泌，催進セラル ルキ認ム。Pepsin 液腹腔内二注入シタル場合ニハ一般二分泌，惹起七ラル、キ認 ムルコト困難ナ゙リ。

9) 小胃胃液Pepsin力八小胃粘液分泌卜步調キーニシ分泌，經過二於テ分泌量 大體反比例テナシテ增減シ分泌ノ初期ニ於テハ粘液ト同樣一般二高值き示セドモ其後 ノ分泌經過二於テハPepsin 八滿遍ナク分泌七ラル。以上ハ胃底腺ノ中等度, 分泌二 於テ見ラル、所ナルモ若シ胃底腺キシテ一時二强力ナル分泌タ起サシムルカ又八極メ テ短時間內二屚了新タナル分泌子惹起七シムルトキハ遂二ハ分泌量/減少キ來スノ ナラズPepsin力ニ於テモ著明ナル隇少キ示ス。

生理的二分泌七ラレタル胃液ハ再ビ吸收セラレテ自己腺細胞二到達シ之レガ分泌機 能二利用七ラル、モノナラン. 而シテ小胃犬二於テ認メ得タル以上/事實八明カ二此 關係キ立證スルモノニシテ宮川教授ノ直接作用說ニ一致スルモノト思惟ス。

第 1 報キ終ルニ臨 $゙$ 長與所長二敬意タ表シ御指導御粳撻キ睗ハリタル宮川敎授二深 謝入. 


\section{主要文蹶}

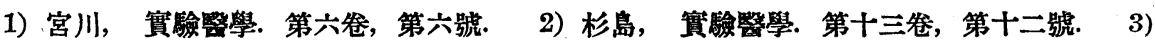
Nechoroschew, N. P., Beiträge zur Kenntnis der periodischen Tätigkeit des Verdauungskanals. I Mitt. Bull. de l'inst. Lesgaft 9, 1. 1925. Zit. nach Babkin. 4) Babkin. B. P., Die äußere Sekretion der Verdauungsdrüsen. 5) Blondlot, N., Traité analytiques de la digestion. Paris 1843. S. 214 ff. Zit. nach Babkin. 6) Gross, Verhandl. d. Ges. russ. Ärzte zu St. Petersburg 1905/06. Februar. Zit. nach Babkin. 7) Krshyschkowsky, Diss. St. Petersburg. 1906. Zit. nach Babkin. 8) Zeljony, Arch. d. Sciences Biol. 17, Nr. 5. 1912. Zit. nach Babkin. 9) Lim, Ivy and Mc. Carthy, Quart. Journ. of Exp. physiol. 15, 13. 1925. Zit. nach Babkin. 10) Sokolow, Diss. St. Petersburg 1904. Zit. nach Babkin. 11) Frouin, Soc. biol. 62. 80. 1907. 12) Frouin, Cpt. rend. des séances de la soc. de biol. 58, 887. 1905. 13）兒玉, 實驗嬁學. 第入卷, 第五號. 14） Boenheim; F., Arch. f. Verdauungskrankh. 35, 186, 1925. Zeitschr. f. d. ges. exp. Med. 12, 295 u. 302, 1921. 15) Rosemann, R., Pflügers Arch. f. d. ges. Physiol. 166, 609, 1917 und 118, 467, 1907. 16) 清水彥大郎, 松井董作, 臺彎醫學會雜誌. 30 替. 7 號. 17) Luckhard, Keeton, Koch and La Mer, Amer. Journ. of Physiol., 50, 527, 1919-20. 18) Pawlow und SchumawSimanowski, Wratsch. 1890, Nr. 41, Zit. nach Babkin. 19) Heidenhain, Hermanns Handbuch d. Physiol. 5, 1 Teil, 158. 1883. Zit. nach Babkin. 20) Ketscher, Diss. St. Petersburg. 1890, Zit. nach Babkin. 21) 栗原阰一, 賽驗消化器病學, 第六炝. 第九號. 22)

Cohen, S. J., Journ. of Biol. Chem., 41, 257, 1920. 